\title{
EFFECTS OF MANAGEMENT PRACTICES ON GRASSLAND BIRDS:
}

\section{UPLAND SANDPIPER}

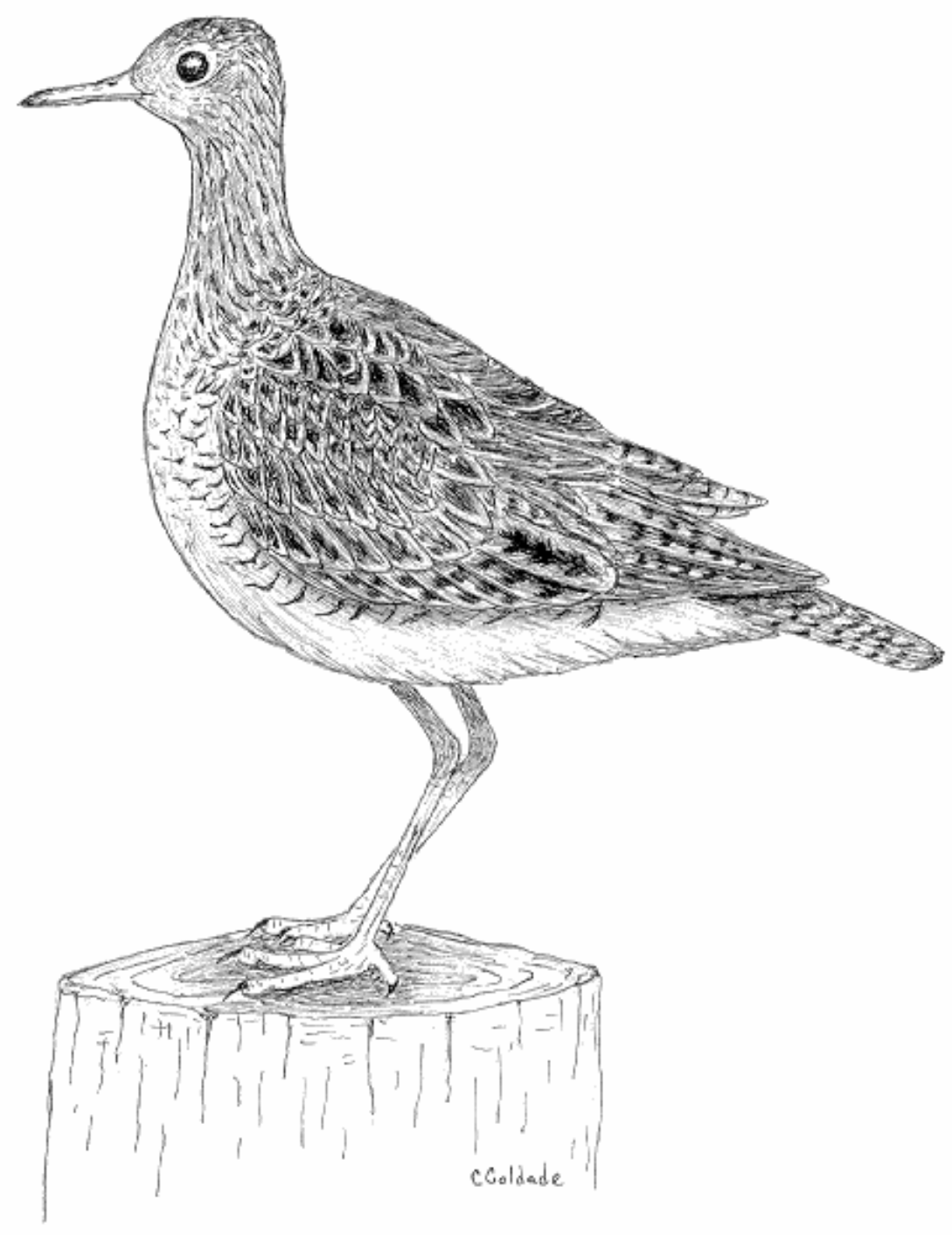

Grasslands Ecosystem Initiative

Northern Prairie Wildlife Research Center

U.S. Geological Survey

Jamestown, North Dakota 58401 
This report is one in a series of literature syntheses on North American grassland birds. The need for these reports was identified by the Prairie Pothole Joint Venture (PPJV), a part of the North American Waterfowl Management Plan. The PPJV recently adopted a new goal, to stabilize or increase populations of declining grassland- and wetland-associated wildlife species in the Prairie Pothole Region. To further that objective, it is essential to understand the habitat needs of birds other than waterfowl, and how management practices affect their habitats. The focus of these reports is on management of breeding habitat, particularly in the northern Great Plains.

Suggested citation:

Dechant, J. A., M. F. Dinkins, D. H. Johnson, L. D. Igl, C. M. Goldade, B. D. Parkin, and B. R. Euliss. 1999 (revised 2002). Effects of management practices on grassland birds: Upland Sandpiper. Northern Prairie Wildlife Research Center, Jamestown, ND. 34 pages.

Species for which syntheses are available or are in preparation:

American Bittern
Mountain Plover
Marbled Godwit
Long-billed Curlew
Willet
Wilson's Phalarope
Upland Sandpiper
Greater Prairie-Chicken
Lesser Prairie-Chicken
Northern Harrier
Swainson's Hawk
Ferruginous Hawk
Short-eared Owl
Burrowing Owl
Horned Lark
Sedge Wren
Loggerhead Shrike
Sprague’s Pipit

Grasshopper Sparrow

Baird's Sparrow

Henslow's Sparrow

Le Conte's Sparrow

Nelson's Sharp-tailed Sparrow

Vesper Sparrow

Savannah Sparrow

Lark Sparrow

Field Sparrow

Clay-colored Sparrow

Chestnut-collared Longspur

McCown's Longspur

Dickcissel

Lark Bunting

Bobolink

Eastern Meadowlark

Western Meadowlark

Brown-headed Cowbird 


\section{EFFECTS OF MANAGEMENT PRACTICES ON GRASSLAND BIRDS:}

\section{UPLAND SANDPIPER}

Jill A. Dechant, Meghan F. Dinkins, Douglas H. Johnson, Lawrence D. Igl, Christopher M. Goldade, Barry D. Parkin, and Betty R. Euliss

Series Coordinator: Douglas H. Johnson

Series Assistant Coordinator: Lawrence D. Igl

Reviewer: C. Stuart Houston

Range Map: Jeff T. Price

Cover Art: Christopher M. Goldade

Major Funding: Prairie Pothole Joint Venture, U.S. Fish and Wildlife Service U.S. Geological Survey

Funding also provided by: U.S. Forest Service

The Nature Conservancy

\section{Collaborators:}

Louis B. Best, Iowa State University

Carl E. Bock, University of Colorado

Brenda C. Dale, Canadian Wildlife Service

Stephen K. Davis, Saskatchewan Wetland Conservation Corporation

James J. Dinsmore, Iowa State University

James K. Herkert, Illinois Endangered Species Protection Board

Fritz L. Knopf, Midcontinent Ecological Science Center

Rolf R. Koford, Iowa Cooperative Fish and Wildlife Research Unit

David R. C. Prescott, Alberta NAWMP Centre

Mark R. Ryan, University of Missouri

David W. Sample, Wisconsin Department of Natural Resources

David A. Swanson, Ohio Division of Wildlife

Peter D. Vickery, Massachusetts Audubon Society

John L. Zimmerman (retired), Kansas State University

June 1999

(revised January 2002) 


\section{ORGANIZATION AND FEATURES OF THIS SPECIES ACCOUNT}

Information on the habitat requirements and effects of habitat management on grassland birds were summarized from information in more than 4,000 published and unpublished papers. A range map is provided to indicate the relative densities of the species in North America, based on Breeding Bird Survey (BBS) data. Although birds frequently are observed outside the breeding range indicated, the maps are intended to show areas where managers might concentrate their attention. It may be ineffectual to manage habitat at a site for a species that rarely occurs in an area. The species account begins with a brief capsule statement, which provides the fundamental components or keys to management for the species. A section on breeding range outlines the current breeding distribution of the species in North America, including areas that could not be mapped using BBS data. The suitable habitat section describes the breeding habitat and occasionally microhabitat characteristics of the species, especially those habitats that occur in the Great Plains. Details on habitat and microhabitat requirements often provide clues to how a species will respond to a particular management practice. A table near the end of the account complements the section on suitable habitat, and lists the specific habitat characteristics for the species by individual studies. A special section on prey habitat is included for those predatory species that have more specific prey requirements. The area requirements section provides details on territory and home range sizes, minimum area requirements, and the effects of patch size, edges, and other landscape and habitat features on abundance and productivity. It may be futile to manage a small block of suitable habitat for a species that has minimum area requirements that are larger than the area being managed. The Brown-headed Cowbird (Molothrus ater) is an obligate brood parasite of many grassland birds. The section on cowbird brood parasitism summarizes rates of cowbird parasitism, host responses to parasitism, and factors that influence parasitism, such as nest concealment and host density. The impact of management depends, in part, upon a species' nesting phenology and biology. The section on breeding-season phenology and site fidelity includes details on spring arrival and fall departure for migratory populations in the Great Plains, peak breeding periods, the tendency to renest after nest failure or success, and the propensity to return to a previous breeding site. The duration and timing of breeding varies among regions and years. Species' response to management summarizes the current knowledge and major findings in the literature on the effects of different management practices on the species. The section on management recommendations complements the previous section and summarizes specific recommendations for habitat management provided in the literature. If management recommendations differ in different portions of the species' breeding range, recommendations are given separately by region. The literature cited contains references to published and unpublished literature on the management effects and habitat requirements of the species. This section is not meant to be a complete bibliography; a searchable, annotated bibliography of published and unpublished papers dealing with habitat needs of grassland birds and their responses to habitat management is posted at the Web site mentioned below.

This report has been downloaded from the Northern Prairie Wildlife Research Center WorldWide Web site, www.npwrc.usgs.gov/resource/literatr/grasbird/grasbird.htm. Please direct comments and suggestions to Douglas H. Johnson, Northern Prairie Wildlife Research Center, U.S. Geological Survey, 8711 37th Street SE, Jamestown, North Dakota 58401; telephone: 701253-5539; fax: 701-253-5553; e-mail: Douglas_H_Johnson@usgs.gov. 


\section{UPLAND SANDPIPER}

\section{(Bartramia longicauda)}

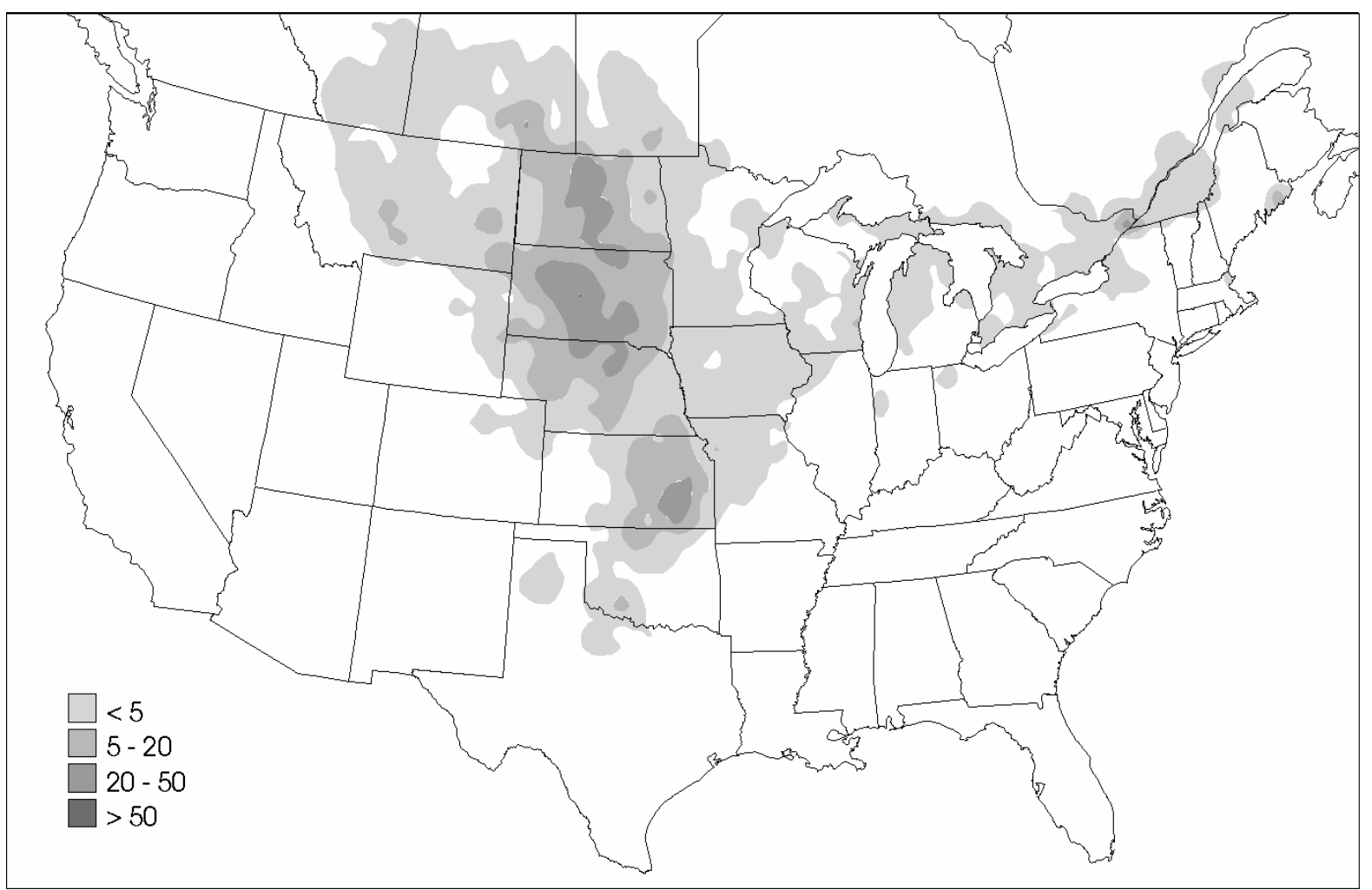

Figure. Breeding distribution of the Upland Sandpiper in the United States and southern Canada, based on Breeding Bird Survey data, 1985-1991. Scale represents average number of individuals detected per route per year. Map from Price, J., S. Droege, and A. Price. 1995. The summer atlas of North American birds. Academic Press, London, England. 364 pages.

Key to management is providing grasslands of various heights with few shrubs. Upland Sandpipers require short vegetation for foraging, taller vegetation for nesting, and short to medium vegetation for brood cover. In general, Upland Sandpipers forage in vegetation $<30 \mathrm{~cm}$ high, nest in vegetation 10-64 cm high, and rear broods in vegetation usually $<15 \mathrm{~cm}$ high.

\section{Breeding range:}

Upland Sandpipers breed from northeastern British Columbia to southwestern Ontario, south to northeastern Oregon, Idaho, Wyoming, Colorado, and Oklahoma, east to Virginia and along the East Coast north to New Brunswick (National Geographic Society 1987). (See figure for the relative densities of Upland Sandpipers in the United States and southern Canada, based on Breeding Bird Survey data.) An isolated population breeds in southeastern Alaska, northern British Columbia, and southwestern Yukon Territories.

\section{Suitable habitat:}

In general, Upland Sandpipers use areas with low to moderate forb cover, low woody cover, moderate grass cover, moderate to high litter cover, and little bare ground (Buss and 
Hawkins 1939, Rotenberry and Wiens 1980, Renken 1983, Skinner et al. 1984, Sample 1989, Kantrud and Higgins 1992, Hull et al. 1996). Fence posts or other display perches may be important components of suitable habitat (Bent 1962, Salt and Salt 1976, White 1983). Upland Sandpipers use native and tame grasslands, wet meadows, hayland, pastures, planted cover (e.g., Conservation Reserve Program [CRP] and dense nesting cover [DNC]), cropland, highway and railroad rights-of-way, and grassy areas of airports (Bates 1907, Bent 1962, Goering 1964, Oetting and Cassel 1971, Higgins 1975, Stewart 1975, Johnsgard 1980, White 1980, Renken 1983, Messmer 1985, Renken and Dinsmore 1987, Snyder et al. 1987, Sample 1989, Kantrud and Higgins 1992, Johnson and Schwartz 1993, Johnson and Igl 1995, King and Savidge 1995, Hull et al. 1996). In Wisconsin, Upland Sandpipers were more numerous in non-forested areas with level terrain and with large, unfragmented agricultural fields, preferably hay, oats, or pasture, but not corn (White 1980, 1983).

In North Dakota, South Dakota, Montana, Wyoming, Colorado, and Nebraska, densities of Upland Sandpipers were highest in areas with moderately grazed typic ustoll soils (Kantrud and Kologiski 1982). Upland Sandpipers were associated with silty range and thin upland range sites in North Dakota; these sites were characterized by thin topsoil, loamy soil, 1-25\% slope, grassy cover, low shrub cover, and moderate to high litter cover (Messmer 1990). Maximum vegetation height ranged from 50 to $70 \mathrm{~cm}$ and average litter depth ranged from 3.8 to $9.1 \mathrm{~cm}$. Sedivec (1994), however, in the same study area found that Upland Sandpipers preferred overflow range sites (areas receiving more than normal soil moisture because of run-off from higher land or from flooding) to silty range sites. In Kansas, Upland Sandpipers appeared to prefer clay, upland range sites and to avoid loamy, upland range sites and limestone breaks (Bowen 1976). In Wisconsin, Upland Sandpipers were found on areas of Clyde silt loam and peat, but did not use Miami silt loam, possibly because these areas supported trees (Buss and Hawkins 1939).

In general, Upland Sandpipers forage within short vegetation and nest and rear broods within taller vegetation. However, time of day, daily activities, and phase of nesting cycle also influence habitat use (Dorio 1977, Dorio and Grewe 1979, Bolster 1990). For example, in Colorado, Upland Sandpipers were encountered most frequently on heavily grazed (average vegetation $<10 \mathrm{~cm}$ high) pastures and on cut and baled alfalfa (Medicago sativa) fields during the morning; during the evening, they preferred bare ground and small-grain fields (vegetation $<27 \mathrm{~cm}$ high) (Bolster 1990). This account will first present information on foraging, followed by nesting, then brood rearing.

Upland Sandpipers prefer short vegetation for foraging. Upland Sandpipers exhibited seasonal use of foraging habitats in Minnesota (Dorio 1977, Dorio and Grewe 1979). Upon first arriving on the breeding grounds, Upland Sandpipers used plowed and seeded fields; in May, sedge (Carex)/grass meadows were used until vegetation was $30 \mathrm{~cm}$ high; overgrazed pastures were used in May and June; and mowed fields of red clover (Trifolium pratense) were used in late summer when vegetation was $2.5-15.0 \mathrm{~cm}$ high. In Wisconsin, a few sandpipers were observed foraging in plowed and fallow (previously pasture, but plowed and left idle) fields and recently seeded corn fields, in which corn was 5-10 cm high (Ailes 1976, Ailes and Toepfer 1977). The corn field was no longer used when the corn was $>15 \mathrm{~cm}$ high. Overall, however, idle fields, plowed fields, and cropland were used infrequently for foraging, and feeding occurred mostly in grazed pastures, followed by ungrazed pastures and hayfields (Ailes 1976). Upland Sandpipers foraged in pastures and corn fields before corn emerged and while corn was 
still short (Ducey and Miller 1980). Graber and Graber (1963) suggested that open and idle fields and cropland were used for foraging in Illinois. In Minnesota, both young and adults preferred to feed in vegetation $<10 \mathrm{~cm}$ high (Dorio 1977, Dorio and Grewe 1979). In Kansas, Zimmerman (1993) surmised that Upland Sandpiper was most abundant in annually burned grassland because it used these areas as foraging habitat. Goering (1964) found Upland Sandpipers foraged in areas with short grass, especially burned pasture, upon their arrival in spring. In Nebraska, Upland Sandpipers foraged in wheat stubble (Bates 1907).

Upland Sandpipers nest in a variety of habitats and vegetation heights and densities, from idle prairie with dense, homogeneous vegetation to wet meadows, oldfields, pastures, hayland, cropland, tame vegetation, burned areas, and sandy areas with sparse vegetation (Musselman 1935, Buss and Hawkins 1939, Bent 1962, Graber and Graber 1963, Goering 1964, Higgins 1975, Ailes 1976, Dorio 1977, Dorio and Grewe 1979, White 1980, Buhnerkempe and Westemeier 1988, Colwell and Oring 1990, Kantrud and Higgins 1992, Faanes and Lingle 1995). Nests may occur in depressions covered by grass arching over the top, in grass clumps, in dense vegetation, or at the base of forbs or shrubs (Lindmeier 1960, Bent 1962, Ailes 1976, Salt and Salt 1976, Skinner et al. 1984). In Wisconsin, Upland Sandpiper territories included loafing, nesting, and feeding sites; loafing and feeding sites were near nesting sites, and were shared by several pairs (Buss and Hawkins 1939). Suitable loafing areas were pastures with low-growing grass clumps, sparsely vegetated prairie, or open hayland. Choice of nesting site may change as the season progresses; early nests were located in pasture and later nests were in ungrazed prairie. Prior to the time when Upland Sandpipers in Colorado began incubating nests, they used heavily grazed fields more often and weedy fields less often than expected (Bolster 1990). During incubation, Upland Sandpipers appeared to prefer lightly grazed fields (average vegetation $17-23 \mathrm{~cm}$ tall) and small-grain fields (vegetation $<27 \mathrm{~cm}$ tall), and to use tall ( $>27$ $\mathrm{cm}$ ) alfalfa and small-grain fields (vegetation $\geq 27 \mathrm{~cm}$ tall) less than expected (Bolster 1990). White (1983) found that $38 \%$ of 553 nests were in pastures, one-fifth of which were in burned pastures. An additional $28 \%$ of nests were in tallgrass prairie, $7 \%$ in hayfields, and the remainder in woody areas, cropland, wetlands, and idle fields adjacent to airport runways.

Vegetation height around the majority of nests ranges from 10.2 to $63.5 \mathrm{~cm}$ (Lindmeier 1960, Goering 1964, Higgins et al. 1969, Ailes 1976, Kaiser 1979, Buhnerkempe and Westemeier 1988, Eldridge 1992). In North Dakota, South Dakota, Montana, and Manitoba, nests were located in grass-dominated sites with $100 \%$ visual obstruction at $<15 \mathrm{~cm}$, effective vegetation height $<30 \mathrm{~cm}$, and 30-99\% litter cover (Kantrud and Higgins 1992); Upland Sandpipers avoided nesting where visual obstruction was $>40 \mathrm{~cm}$ or vegetation height was $>85$ $\mathrm{cm}$. In South Dakota, nest concealment for nests in grazed prairie was measured from various angles: all nests had $\geq 50 \%$ vertical concealment by residual and living vegetation, $33 \%$ of nests were concealed on all sides, 55\% were concealed on two sides, and 12\% had no side concealment (Kaiser 1979). In Wisconsin, Upland Sandpipers did not initiate nests in vegetation $>40 \mathrm{~cm}$ tall, although when eggs hatched, vegetation was as tall as $70 \mathrm{~cm}$ (Ailes 1976, 1980). In North Dakota, Upland Sandpipers most commonly nested in areas where grass accounted for $\geq 50 \%$ canopy cover and forbs for $<50 \%$ canopy cover (Bowen and Kruse 1993). Other habitats used for nesting were those in which forbs accounted for $\geq 50 \%$ canopy cover and grass for $<50 \%$ canopy cover, in which western snowberry (Symphoricarpos occidentalis) with a grass understory accounted for $<50 \%$ canopy cover, and in which grass accounted for $\geq 50 \%$ canopy cover and forbs for $<50 \%$ canopy cover; habitats in which western snowberry with a grass 
understory accounted for $\geq 50 \%$ canopy cover were avoided. In northwestern Minnesota, vegetation height measured within $10 \mathrm{~d}$ after the first egg was laid averaged $25.4 \mathrm{~cm}$, and consisted largely of residual vegetation (Lindmeier 1960). Standing vegetation over Upland Sandpiper nests was fairly thin, with a light intensity average of 222 candles $/ \mathrm{m}^{2}$ for 12 nests. In another study in northwestern Minnesota, mean vegetation measurements from 40 sampling points within four Upland Sandpiper territories were $79 \mathrm{~cm}$ vegetation height, 35\% ground cover (coverage of live vegetation with a total height of $\leq 10 \mathrm{~cm}$ ), and $24 \mathrm{~cm}$ phanerophyte height (Niemi and Hanowski 1983). Phanerophytes were defined as shrubs, forbs, or graminoids $>40$ $\mathrm{cm}$ high and present each year. In Saskatchewan, Upland Sandpipers nested in tall, dense, homogeneous vegetation $>15 \mathrm{~cm}$ in height (Colwell and Oring 1988).

No clear pattern of preference for native versus tame vegetation over the breeding range of the Upland Sandpiper is discernible. In central Wisconsin and central Minnesota, Upland Sandpipers were found nesting in tame vegetation; study areas, however, may have contained little or no native vegetation (Ailes 1976, Dorio 1977). In northwestern Minnesota, 20 of 22 nests were found in native grasses; the other two were in alfalfa (Lindmeier 1960). Likewise, in southeastern Wisconsin, nests were placed in both tame and native vegetation; two nests were found in legumes (alfalfa and sweet clover [Melilotus sp.]) (Buss and Hawkins 1939). Musselman (1935) noted that Upland Sandpipers in Missouri and Illinois nested within abandoned clover (no scientific name provided) fields and grass. In Illinois, Upland Sandpipers preferred stands of Kentucky bluegrass (Poa pratensis) and other tame grass species as opposed to tallgrass prairie, and preferred older ( $>5 \mathrm{yr}$ ) plantings of tame grasses and forbs (Birkenholz 1973, Buhnerkempe and Westemeier 1988). In Kansas, Upland Sandpipers nested in tallgrass as well as in tame grasses (Goering 1964). In a study encompassing Great Plains grasslands, areas considered to be the best habitat for Upland Sandpipers were dominated by wheatgrass (Agropyron) and Kentucky bluegrass, followed by green needlegrass (Stipa viridula), buffalo grass (Buchloe dactyloides), western snowberry, and slimspike three-awn (Aristida longiseta) (Kantrud and Kologiski 1982). Dominant vegetation at nest sites in North Dakota, South Dakota, Montana, and Manitoba were Kentucky bluegrass, smooth brome (Bromus inermis), needle-and-thread (Stipa comata), and quackgrass (Agropyron repens); although most nests were located within mixed-grass, Upland Sandpipers readily nested in stands of tame grasses (Kantrud and Higgins 1992). King and Savidge (1995) observed Upland Sandpipers in CRP fields seeded warm-season grasses and native tallgrass in Nebraska. Within ungrazed grasslands in North Dakota and South Dakota, 38 of 41 nests were in either native or tame grasses located in idle fields or in rights-of-way; one of these nests was in alfalfa and brome (Higgins et al. 1969). The other three nests were in pasture. Within grazed grasslands in North Dakota, vegetation within 1 $\mathrm{m}$ of nests was composed of native grasses and small amounts of tame grasses such as Kentucky bluegrass and smooth brome (Bowen and Kruse 1993). In South Dakota, Upland Sandpipers nested only in native prairie; 32 of the 33 nests were in prairie classified as in good or excellent range condition (Kaiser 1979). In Manitoba, numbers of Upland Sandpipers were positively correlated with presence of native vegetation and negatively correlated with presence of tame vegetation (Wilson and Belcher 1989). In Saskatchewan, Upland Sandpipers were present in low abundance in both native mixed-grass and tame grasslands dominated by crested wheatgrass (Agropyron cristatum) (Sutter and Brigham 1998).

Moderate amounts of forbs may be an important component in suitable nesting habitat (Skinner 1975, Renken 1983, Buhnerkempe and Westemeier 1988, Klute 1994, Hull et al. 1996, 
Klute et al. 1997). In North Dakota Waterfowl Production Areas, Upland Sandpipers used plots that had $57.4 \%$ grass cover and $23.5 \%$ forb cover (Renken 1983). In Illinois Greater PrairieChicken (Tympanuchus cupido) sanctuaries, Upland Sandpipers preferred to nest in fields containing a mixture of grasses and forbs; they preferred fields of seeded grasses that were being invaded by forbs (Buhnerkempe and Westemeier 1988). In Kansas tallgrass, Upland Sandpipers were significantly more abundant in pasture than in CRP; grazed pastures had significantly greater coverage of total vegetation, live vegetation, grasses, and forbs than did CRP (Klute et al. 1997). In Kansas CRP fields, Upland Sandpipers were present in fields described as having a medium frequency of occurrence of forbs (Hull et al. 1996). Skinner (1974) found fewer Upland Sandpipers in fields that were predominantly forbs than in fields with scattered forbs or with no forbs.

Upland Sandpipers require grasslands of various heights for rearing broods. In Minnesota, broods used weedy fields, open areas within oldfields, and overgrazed pastures (Dorio 1977, Dorio and Grewe 1979). Marshy areas of sedge and cattails (Typha) that had dried during drought were used as escape cover by broods (Dorio 1977). In Wisconsin, brood rearing occurred mostly in heavily grazed (vegetation $<10 \mathrm{~cm}$ tall) pastures, followed by ungrazed pastures and hayfields (Ailes 1976). Some broods were observed in idle fields, plowed fields, and cropland. Late-summer feeding occurred mainly in heavily and moderately grazed pastures; lightly grazed pastures were used infrequently (Ailes 1980). In Illinois, broods were observed in wheat stubble, recently hayed legumes, redtop (Agrostis stolonifera) intermixed with weeds, and moderately grazed pastures (Buhnerkempe and Westemeier 1988). In Colorado, brood rearing occurred within short ( $<27 \mathrm{~cm}$ high) and cut alfalfa and small-grain fields (vegetation $<27 \mathrm{~cm}$ tall) more often than expected, whereas small-grain fields (vegetation $\geq 27 \mathrm{~cm}$ tall) were used less often than expected (Bolster 1990). Bolster (1990) observed a noticeable movement of broods from pastures to alfalfa fields. During pre-migration, heavily grazed fields, and cut and baled alfalfa were used more often, and lightly grazed fields, weedy fields, tall alfalfa, and smallgrain fields (vegetation $\geq 27 \mathrm{~cm}$ ) were used less often than expected. A table near the end of the account lists the specific habitat characteristics for Upland Sandpipers by study.

\section{Area requirements:}

Territory size in Wisconsin was 8-12 ha (Wiens 1969). Upland Sandpipers are highly sensitive to habitat fragmentation (Herkert 1991a, Herkert et al. 1993, Vickery 1993, Winter 1998). Abundance has been positively correlated to field or patch size (Herkert 1994, Vickery et al. 1994, Bollinger 1995, Helzer 1996). In Illinois, Upland Sandpipers required areas $>30$ ha (Herkert 1991b,c). In southwestern Missouri, Upland Sandpipers occurred only on tallgrass prairie fragments $>75$ ha in size (Winter 1998). In Nebraska, Upland Sandpipers required a minimum area of 50-61 ha to reach 50\% incidence, with a perimeter-area ratio of 0.008 (Helzer 1996, Helzer and Jelinski 1999). Occurrence of Upland Sandpipers was positively correlated with patch area and inversely correlated with perimeter-area ratio (Helzer and Jelinski 1999). In Maine, Upland Sandpipers were rare in areas $<50$ ha, and reached 50\% incidence at 200 ha (Vickery 1993, Vickery et al. 1994).

Brown-headed Cowbird brood parasitism:

Brood parasitism by Brown-headed Cowbirds (Molothrus ater) appears to be infrequent in Upland Sandpiper nests (Friedmann 1963, Friedmann and Kiff 1985). Documented rates of 
parasitism are $0 \%$ of 28 nests (M. Winter and D. H. Johnson, unpublished data), 1\% of 189 nests (Higgins and Kirsch 1975), and 5\% of 43 nests (Faanes and Lingle 1995). Upland Sandpipers are unsuitable hosts because their young are precocial.

Breeding-season phenology and site fidelity:

Upland Sandpipers arrive on the breeding grounds from early April to early May (Buss and Hawkins 1939; Lindmeier 1960; Bent 1962; Goering 1964; Maher 1973; Higgins and Kirsch 1975; Ailes 1976, 1980; Bowen 1976; Dorio 1977; Johnsgard 1980; Buhnerkempe and Westemeier 1988; Kantrud and Higgins 1992) and depart from mid-July to late August (Buss and Hawkins 1939; Bent 1962; Goering 1964; Maher 1973; Wiens 1969; Higgins and Kirsch 1975; Ailes 1976, 1980; Dorio 1977; Johnsgard 1980; Bolster 1990). Upland Sandpipers sometimes nest semicolonially (Buss and Hawkins 1939, Bowen 1976, Bowen and Kruse 1993). Breeding-site fidelity has been observed (Ailes 1976, 1980; Bowen 1976; Dorio 1977). Seasonal time limitations make double-broodedness in Upland Sandpiper unlikely; however, renesting following failure of initial nests has been observed (Buss and Hawkins 1939, Lindmeier 1960, Dorio and Grewe 1979).

Species' response to management:

Bent (1962) reported that burning and cultivation of mixed-grass prairie in Saskatchewan forced Upland Sandpipers to nest in cultivated fields. Also in Saskatchewan, Upland Sandpipers used a burned plot 2-3 yr postburn during 3 yr of postburn monitoring, but were not observed on an unburned plot (Pylypec 1991). In Minnesota, a 75\% reduction in nesting cover due to spring fire may have reduced the numbers of Upland Sandpipers the year of the burn (Lindmeier 1960); numbers of breeding pairs returned to pre-burn levels the following year. Likewise, in Wisconsin, burning reduced or eliminated nesting in fields where nesting had occurred in the year previous to the burn (Buss and Hawkins 1939). In mixed-grass prairie in North Dakota, Upland Sandpipers were most abundant immediately following a burn and 1 yr postburn, as compared to 2-15 yr postburn (Johnson 1997). Upland Sandpipers used a burned native pasture in South Dakota significantly more than an unburned pasture (Huber and Steuter 1984). In Illinois tallgrass, Upland Sandpipers were most abundant 2 yr postburn, but were absent 3 yr postburn (Herkert 1994). In Illinois grasslands that were seeded to both native and tame grasses, Upland Sandpipers preferred nesting in fields $1 \mathrm{yr}$ postburn. Burned fields were not preferred in the following years, and number of nesting seasons since fields were burned did not affect nest density (Buhnerkempe and Westemeier 1988).

Several burning-related studies have been conducted in the Kansas Flint Hills. Upland Sandpipers appeared to use unburned areas for nesting and foraging and annually burned grassland for foraging (Zimmerman 1993). Goering (1964) found nests in burned native grasses, as well as in heavily grazed and ungrazed native and tame grasses. Eddleman (1974) observed Upland Sandpipers on heavily grazed/annually burned pasture, moderately grazed/unburned pasture, and ungrazed/burned areas; Upland Sandpipers did not use unburned/ungrazed areas. Robel et al. (1998) found that Upland Sandpipers were present only on spring-burned, seedednative CRP fields and not on unburned fields. Bowen (1976) observed that Upland Sandpiper abundance did not differ between burned and unburned pastures in Kansas. Upland Sandpipers appeared to prefer burned, loamy, upland range sites over all other burned range sites and used unburned and burned shallow and claypan range sites in proportion to their abundance; used 
unburned and burned, clay, upland range sites more than expected based on abundance; and used unburned and burned, loamy upland and limestone breaks less than expected.

Upland Sandpipers occurred at higher densities in hayland than pasture and wet prairie in Wisconsin, although differences in densities were not statistically significant (Sample 1989). However, mowing may cause nest failure: three destroyed nests were found in a Nebraska alfalfa field following mowing (Ducey and Miller 1980). Hayfields were preferred over seed-combined fields in Missouri, and were used for foraging and loafing (Skinner 1974). Similarly, in Illinois grasslands that were seeded to both native and tame grasses, Upland Sandpipers preferred nesting in fields $1 \mathrm{yr}$ after being rotary mowed, whereas grass meadows harvested for seed the previous year were used as nesting habitat less than other grasslands (Buhnerkempe and Westemeier 1988). In North Dakota, Upland Sandpipers used previously idled areas only after mowing (Messmer 1990). Upland Sandpipers were located in annually mowed native prairie in Iowa (Kendeigh 1941).

Because some studies report only the presence of Upland Sandpipers and not how they use grazed areas, it is difficult to give a general statement on effects of grazing on Upland Sandpipers. Besides nesting, Upland Sandpipers use grazed areas for foraging and brood rearing (Ailes 1976, Dorio 1977). Nest loss occasionally occurs as a result of trampling by cattle (Buss and Hawkins 1939; Ailes 1976, 1980; Dorio 1977; Bowen and Kruse 1993). Four studies were designed to determine the effect of grazing on productivity. Messmer (1990) and Sedivec (1994) compared rotational grazing systems, specifically short-duration grazing and twice-over rotation grazing, to season-long grazing and to idle grasslands. Short-duration grazing involves a system of pastures rotated through a grazing schedule of about 1 wk grazed and 1 mo ungrazed, repeated throughout the season (usually late May or early June until October). Twice-over rotation involves grazing a number of pastures twice per season, with about a 2-mo rest in between grazing. Season-long grazing involves leaving cattle on the same pasture all growing season. Bowen and Kruse (1993) and Kirsch and Higgins (1976) examined seasonality and intensity of grazing, respectively. All four studies were conducted in southcentral North Dakota in mixedgrass prairie.

Research by Messmer $(1985,1990)$ revealed that nest density and nest success were highest with twice-over deferred and season-long grazing systems than on idle pastures, but that average density of breeding sandpipers was highest on the short-duration grazing system. In a continuation of Messmer's study, Sedivec (1994) reported that nest density was significantly higher on grazed than on idle grasslands. Both authors concluded that grazing is compatible with breeding needs of Upland Sandpipers

Bowen and Kruse (1993) compared nest density between the four grazing practices of autumn grazing, autumn-and-spring grazing, season-long grazing, and spring grazing to nongrazed areas. Nest densities were lower in pastures subjected to grazing during the nesting season (autumn-and-spring grazing, season-long grazing, and spring grazing) than in control fields or fields with autumn grazing. Nest densities did not differ between spring grazing with high stocking density (3.7 head of cattle/ha and grazing rate of 3.10 animal unit months $[\mathrm{AUM}] / \mathrm{ha}$ ) to that of season-long grazing with low stocking density (1.0 head of cattle/ha and grazing rate of $2.45 \mathrm{AUM} / \mathrm{ha}$ ). Nest densities were significantly lower in years after pastures had been subjected to season-long and autumn-and-spring grazing than in the year before grazing treatments occurred (Bowen and Kruse 1993). 
Within mixed-grass and tallgrass prairie in South Dakota, nest densities did not differ between idle sites and sites that were grazed in May at a grazing rate of 1.0-2.5 AUM/ha, and in which $20-80 \%$ of the current year's growth was removed (Kaiser 1979). Fourteen nests were found within a 256-ha fragment of moderately grazed prairie in South Dakota (Lokemoen and Duebbert 1974). Kirsch and Higgins (1976) reported that mean nest productivity was lowest on tilled areas (where no nests were observed), higher on grazed and idle areas, and highest on burned areas. The highest nest density of 6.8 nests/40.5 ha was on a grassland burned $2 \mathrm{yr}$ previously. In North Dakota, South Dakota, Montana, and Manitoba, nest success was higher in idle grasslands than in grazed pastures (Kantrud and Higgins 1992). In eastern Kansas, Upland Sandpipers preferred native pasture to CRP seeded to native grasses, both of which were annually burned; nests were found only in pastures (Klute 1994, Klute et al. 1997).

The following researchers looked only at presence or density of Upland Sandpipers on grazed areas, but not specifically at productivity. Kantrud (1981) found that Upland Sandpipers were more attracted to heavily grazed native grasslands in North Dakota than either lightly or moderately grazed, or mowed grasslands, although densities were relatively high in all habitats compared to other bird species. Over a broader range (North Dakota, South Dakota, Montana, Wyoming, Colorado, Nebraska), however, sandpiper densities were highest on moderately grazed typic ustoll soils, and no relationship between density and grazing intensity was found (Kantrud and Kologiski 1982). Upland Sandpiper densities were significantly higher in idle and grazed mixed-grass than in tame DNC; they also occurred in areas 1 yr postgrazing (Renken 1983, Renken and Dinsmore 1987). In Nebraska, Upland Sandpipers were present on areas grazed by cattle and areas that were both grazed by American bison (Bison bison) and burned (Griebel et al. 1998).

In Alberta, Upland Sandpipers were found only on deferred-grazed native areas.

Treatments included tame pastures of crested wheatgrass grazed in spring from late April to midJune, native grassland grazed in early summer, and native grassland grazed after 15 July (deferred); the control was continuously grazed native pasture (Prescott and Wagner 1996). In Saskatchewan, Upland Sandpipers were observed on grazed pastures, but not on ungrazed areas (Dale 1984). In Ontario, Upland Sandpipers preferred lightly grazed pastures over hayland, oldfields, and cropland (Speirs and Orenstein 1967). In Kansas, Upland Sandpipers preferred grazed to ungrazed pastures (Bowen 1976). In Nebraska, avian diversity and density were higher on grazed than ungrazed areas because of the presence of Upland Sandpipers; sandpipers were not present on ungrazed areas (Cole and Sharpe 1976).

In Missouri, Skinner $(1974,1975)$ compared sandpiper density between idle fields and fields subjected to haying, seed-combining, or grazing at four intensities. Density of Upland Sandpipers was highest under moderate grazing (vegetation 10.2-30.4 cm tall, 20-40\% grass and forb cover at $25 \mathrm{~cm}$ tall) and heavy grazing (vegetation $0-10.2 \mathrm{~cm}$ tall, $<20 \%$ grass and forb cover at $25 \mathrm{~cm}$ tall) (Skinner 1975, 1982). Upland Sandpipers were present in hayed, combined, and lightly grazed fields (vegetation $>30.4 \mathrm{~cm}$ tall), but not in idle fields. Nests also were found on grazed tallgrass prairie (Skinner et al. 1984).

Cultivation may negatively impact Upland Sandpipers (Bent 1962, Faanes and Lingle 1995); cultivation eliminates brood-rearing areas and may force broods to inhabit edge habitat (Dorio 1977). In Nebraska, sandpipers preferred untilled areas such as alfalfa and pastures over tilled areas; however, they foraged in corn fields before and just after emergence of vegetation (Ducey and Miller 1980). Hatching success in southcentral North Dakota was lowest on 
annually tilled cropland (none of six nests hatched) and highest on burned and idle grasslands (Kirsch and Higgins 1976). In North Dakota, Upland Sandpipers appeared to prefer minimumtillage (seeding into untilled or moderately tilled land) and organic farming (cultivation and crop rotation, but no chemicals, are used to control weeds) over conventional tillage (spring and fall tillage and use of herbicides); most nests were placed in wheat stands that were physically similar to grasslands (Lokemoen and Beiser 1997). In North Dakota, Higgins (1975) found that Upland Sandpipers preferred nesting in untilled uplands (road rights-of-way, bands of vegetation around wetlands, heavily grazed grasslands, and idled grasslands) over fallow (bare ground), mulched or standing stubble, or growing small grain. In Illinois, preferred nesting habitat was seeded grasses mixed with forbs, such as young, rotary-mowed seedings and older, grass-seed meadows (Buhnerkempe and Westemeier 1988). Sandpipers preferred nesting in fields $>5 \mathrm{yr}$ after seeding, especially in those $>8$ yr old. Fields with homogeneous vegetation, or that were planted to smooth brome, were rarely selected. Grass meadows harvested for seed the previous year were not used.

Upland Sandpipers have been reported as relatively uncommon in CRP and rowcrops compared to other habitats (Kantrud and Higgins 1992, Klute 1994, Best et al. 1997). However, they have been observed in grassed waterways in Iowa cropland (Bryan and Best 1991), and they nested in Iowa CRP fields but not rowcrops (Patterson 1994, Patterson and Best 1996). They were more common in cropland than in CRP fields in North Dakota (Johnson and Igl 1995). Upland Sandpipers were fairly common within CRP fields in Minnesota, North Dakota, South Dakota, and Montana (Johnson and Schwartz 1993) and nested within CRP fields in Iowa (Patterson 1994). Three nests that were found in hayed strips and idled blocks within CRP fields in South Dakota were depredated (Luttschwager and Higgins 1992). In Kansas, no nests were found on spring-burned CRP (Klute 1994, Klute et al. 1997). In Nebraska, Upland Sandpipers were found in both native prairie and in CRP planted to native grasses (King and Savidge 1995). Densities of Upland Sandpipers were higher in idle and grazed native prairie than in DNC (Renken and Dinsmore 1987). Upland Sandpipers were not present in idle fields in Missouri (Skinner 1975). Bowen and Kruse (1993) found that allowing mixed-grass prairie to remain idle for 2-3 yr between grazing treatments was not detrimental to breeding Upland Sandpipers. Thirty-eight of 41 nests located in the Missouri Coteau of North Dakota were in idle grasslands characterized by moderately tall $(15-61 \mathrm{~cm})$ grasses and abundant ground litter (Higgins et al. 1969).

Some pastures were used more frequently during years when they had been fertilized with nitrogen (Bowen 1976). In Wisconsin, fertilizing with manure reduced or completely excluded nesting; however, Upland Sandpipers were found nesting in grass clumps formed around manure droppings (Buss and Hawkins 1939).

\section{Management Recommendations:}

Maintain large (>100 ha), contiguous tracts of prairie to reduce edge, provide habitat heterogeneity, and to decrease nest depredation (Herkert et al. 1993, Herkert 1994, Klute 1994, Helzer 1996). Blocks should be within $1.6 \mathrm{~km}$ of each other and be contiguous with grassy habitats (e.g., pasture, hayfields) (Herkert et al. 1993). Shape, as well as area, of management 
units must be taken into consideration; perimeter-area ratio strongly influenced occurrence of Upland Sandpipers in Nebraska (Helzer and Jelinski 1999).

Maintain native prairie by implementing burning, grazing, or haying treatments, or leaving idle, every 2-3 yr (Kaiser 1979, Kantrud 1981). In South Dakota, Upland Sandpipers successfully nested in pastures stocked in May at 1.0 to 2.5 AUM/ha (Kaiser 1979). In North Dakota, springburning at 3-yr intervals provided habitat conditions needed by Upland Sandpipers for nesting; grazing did to a lesser extent, but was more compatible than cropland or seeding tame grasses (Kirsch and Higgins 1976).

Allow some blocks of grassland to be undisturbed to serve as nesting cover (Lindmeier 1960, Bowen and Kruse 1993).

Avoid burning, mowing, or plowing during the nesting season (Buss and Hawkins 1939, Lokemoen and Beiser 1997). Mowing and spraying of pesticides in CRP should be delayed until after July to avoid disturbances during peak nesting (Bolster 1990, Patterson 1994). Mowing of nesting and brooding habitat should be delayed until 1 July or later (Buhnerkempe and Westemeier 1988).

Provide display perches, such as fence posts, rock piles, or tree stumps (White 1983).

Prevent encroachment of woody vegetation (Herkert et al. 1993).

A complex of fields of different management practices may be necessary to meet Upland Sandpiper needs during the breeding season. Grazed, burned, and hayed fields provide suitable habitat for feeding, loafing, and brood rearing, but undisturbed fields are needed for nesting (Bowen and Kruse 1993). Provide a mosaic of habitat types, such as grassland of various heights and densities as well as cropland, to provide for the needs of Upland Sandpiper throughout the breeding season (Bolster 1990).

Annually burn $20-30 \%$ of grassland fragments $<80$ ha (Herkert 1994). Small fragments should have $<50 \%$ of their area burned at a time, and, if next to other fragments, should be burned in a rotating manner that allows unburned fragments to be next to burned fragments. Burns should occur from March to early April or October to November (Herkert et al. 1993).

Avoid mowing road rights-of-way until late July (Oetting and Cassel 1971).

Graze at moderate levels to provide diverse grass heights and densities (Skinner 1974). Graze using a rotational system of two or more grazing units to increase grass heights and densities within and among units.

Avoid season-long grazing; where grazing is necessary, delay grazing until mid- to late June to maintain nest densities (Bowen and Kruse 1993, Sedivec 1994). Choose rotational grazing over season-long grazing to provide more undisturbed cover during the nesting season by deferring two or more pastures until mid- to late June (Sedivec 1994). With rotational grazing systems, 
delay grazing until late May to early June to benefit nesting sandpipers as well as to optimize calf performance. Follow stocking rates as outlined by the U.S. Soil Conservation Service (1984); rates may be slightly higher for rotational grazing (Sedivec 1994).

Encourage no-till or minimum-till practices instead of annual tillage practices, so that habitat is undisturbed during the nesting season (Kantrud and Higgins 1992, Lokemoen and Beiser 1997). Nest productivity is low on annually tilled cropland and former cropland planted to grass/legumes (Kirsch and Higgins 1976). Encourage adoption of organic farming in cultivated areas, but delay first tillage until late June or early July to prevent destruction of nests (Lokemoen and Beiser 1997).

Maintain heterogeneous fields of cool-season, tame grasses that are $>5$ yr old; to obtain a mixture of forbs and grasses, fields should not be re-seeded until they are 10-12 yr old (Buhnerkempe and Westemeier 1988). Management of seeded grasses includes allowing them to idle, rotary mowing to a height of $15-30 \mathrm{~cm}$ on a 3-yr rotation, or burning. Moderate grazing may provide suitable habitat in both native and tame grasses, but more research needs to be done. 
Table. Upland Sandpiper habitat characteristics.

\begin{tabular}{|c|c|c|c|}
\hline Author(s) & Location(s) & Habitat(s) Studied* & Species-specific Habitat Characteristics \\
\hline $\begin{array}{l}\text { Ailes 1976, 1980; } \\
\text { Ailes and Toepfer } \\
1977\end{array}$ & Wisconsin & $\begin{array}{l}\text { Cropland, tame } \\
\text { hayland, tame } \\
\text { pasture, woodland }\end{array}$ & $\begin{array}{l}\text { Foraged in heavily grazed (vegetation }<10 \mathrm{~cm} \text { tall) pasture, } \\
\text { ungrazed pasture, hayland, fallow fields, and recently } \\
\text { plowed corn field (corn } 5-10 \mathrm{~cm} \text { tall); no longer used corn } \\
\text { when it was }>15 \mathrm{~cm} \text { tall. Nested in hayland, idle fields, } \\
\text { grazed and ungrazed pastures, hayland } 1 \text { yr postmowing, and } \\
\text { cover }<40 \mathrm{~cm} \text { tall; did not nest in heavily grazed fields or } \\
\text { cropland. Reared broods in heavily to moderately grazed } \\
\text { (vegetation }<10 \mathrm{~cm} \text { high) fields, ungrazed pastures, } \\
\text { hayfields, idle fields, plowed fields, and cropland }\end{array}$ \\
\hline Bates 1907 & Nebraska & Cropland & Foraged in wheat stubble that contained grain \\
\hline Bent 1962 & Rangewide & $\begin{array}{l}\text { Cropland, burned } \\
\text { mixed-grass, idle } \\
\text { mixed-grass }\end{array}$ & $\begin{array}{l}\text { Preferred open prairies and grassy fields; nested in cultivated } \\
\text { fields, in sandy areas with sparse vegetation, in rough brush, } \\
\text { in long grass and on dry, grassy prairies in slight depressions } \\
\text { in long, thick grass; burning and cultivation of prairies } \\
\text { forced Upland Sandpipers to nest in cultivated fields; } \\
\text { perched on fenceposts, telephone poles, tree stumps, or rocks }\end{array}$ \\
\hline Best et al. 1997 & $\begin{array}{l}\text { Indiana, } \\
\text { Iowa, } \\
\text { Kansas, } \\
\text { Michigan, } \\
\text { Missouri, } \\
\text { Nebraska }\end{array}$ & $\begin{array}{l}\text { Cropland, } \\
\text { Conservation } \\
\text { Reserve Program } \\
\text { (CRP; burned } \\
\text { seeded-native, } \\
\text { burned seeded- } \\
\text { native/tame, burned } \\
\text { tame, idle seeded- } \\
\text { native, idle seeded- } \\
\text { native/tame, idle }\end{array}$ & $\begin{array}{l}\text { Generally uncommon in CRP and in rowcrops, but used } \\
\text { rowcrops (probably for foraging) more often than CRP }\end{array}$ \\
\hline
\end{tabular}




\begin{tabular}{|c|c|c|c|}
\hline & & $\begin{array}{l}\text { tame, seeded- } \\
\text { native/tame hayland, } \\
\text { tame hayland) }\end{array}$ & \\
\hline Birkenholz 1973 & Illinois & $\begin{array}{l}\text { Idle, idle tallgrass, } \\
\text { idle tame, wet } \\
\text { meadow, wetland }\end{array}$ & $\begin{array}{l}\text { Preferred stands of Kentucky bluegrass (Poa pratensis) to } \\
\text { tallgrass prairie }\end{array}$ \\
\hline Bolster 1990 & Colorado & $\begin{array}{l}\text { Bare ground, } \\
\text { cropland, hayland, } \\
\text { idle, pasture }\end{array}$ & $\begin{array}{l}\text { Prior to incubation, used heavily grazed fields more often } \\
\text { and weedy fields less often than expected; in general, used } \\
\text { lightly to moderately grazed pastures and bare ground in } \\
\text { proportion to their availability; used heavily grazed } \\
\text { (vegetation }<10 \mathrm{~cm} \text { tall) pastures, alfalfa (Medicago sativa) } \\
\text { fields with mean height } \leq 27 \mathrm{~cm} \text {, and small-grain fields with } \\
\text { mean height }<27 \mathrm{~cm} \text { more often than predicted; used weedy } \\
\text { fields, alfalfa with mean height }>27 \mathrm{~cm} \text {, and small-grain } \\
\text { fields with mean height } \geq 27 \mathrm{~cm} \text { less often than predicted; } \\
\text { preferred medium-height vegetation of the shortgrass prairie } \\
\text { and grass-like vegetation over tangled vegetation }\end{array}$ \\
\hline $\begin{array}{l}\text { Bowen and Kruse } \\
1993\end{array}$ & North Dakota & $\begin{array}{l}\text { Idle mixed-grass, } \\
\text { mixed-grass pasture }\end{array}$ & $\begin{array}{l}\text { Nested in areas where grass accounts for } \geq 50 \% \text { canopy } \\
\text { cover and forbs for }<50 \% \text { canopy cover; vegetation within } 1 \\
\text { m of nests included Kentucky bluegrass, needle-and-thread } \\
\text { (Stipa comata), green needlegrass (Stipa viridula), western } \\
\text { wheatgrass (Pascopyrum smithii), smooth brome (Bromus } \\
\text { inermis), upland sedges (Carex spp.), and western } \\
\text { snowberry (Symphoricarpos occidentalis). Habitats in } \\
\text { which forbs accounted for } \geq 50 \% \text { canopy cover and grass for } \\
<50 \% \text { canopy cover, in which western snowberry with a } \\
\text { grass understory accounted for }<50 \% \text { canopy cover, and in } \\
\text { which grass accounted for } \geq 50 \% \text { canopy cover and forbs for } \\
<50 \% \text { canopy cover were used for nesting in relation to the } \\
\text { proportion of the vegetation type in the study area. Habitats }\end{array}$ \\
\hline
\end{tabular}




\begin{tabular}{|c|c|c|c|}
\hline & & & $\begin{array}{l}\text { in which western snowberry with a grass understory } \\
\text { accounted for } \geq 50 \% \text { canopy cover were avoided. Majority } \\
\text { of nests ( } 90 \% \text { of } 342 \text { nests) were in vegetation with } \\
\text { height/density readings in early June between } 5 \text { and } 20 \mathrm{~cm} \text {; } \\
\text { nest density was lower on fields grazed during the nesting } \\
\text { season (autumn-and-spring grazing, season-long, and spring } \\
\text { grazing) than fields with autumn grazing; nest density did } \\
\text { not differ between spring grazing with high stocking density } \\
\text { (3.7 head of cattle/ha and grazing rate of } 3.1 \text { animal unit } \\
\text { months [AUM]/ha) and season-long grazing with low } \\
\text { stocking density (1.0 head of cattle/ha and grazing rate of } \\
2.45 \text { AUM/ha); nest density was lower in years after fields } \\
\text { were subjected to season-long and autumn-and-spring } \\
\text { grazing than in years before grazing treatments occurred }\end{array}$ \\
\hline Bowen 1976 & Kansas & $\begin{array}{l}\text { Burned tallgrass } \\
\text { pasture }\end{array}$ & $\begin{array}{l}\text { Used clay, upland range sites more than expected, and } \\
\text { loamy, upland range sites and limestone breaks less than } \\
\text { expected, based on abundance of range sites; used claypan } \\
\text { and shallow range sites in proportion to their abundance; } \\
\text { relative abundance of clay upland was a good predictor of } \\
\text { use; used some pastures more frequently during years when } \\
\text { they were fertilized; preferred grazed to ungrazed pastures } \\
\text { and pastures grazed year-round by cows and calves more } \\
\text { than pastures grazed by steers; there was no difference in use } \\
\text { between burned and unburned pastures; used burned, loamy } \\
\text { upland range sites more frequently than other burned habitat; } \\
\text { used unburned and burned shallow and claypan range sites } \\
\text { in proportion to their abundance; used unburned and burned, } \\
\text { loamy upland and limestone breaks less than expected based } \\
\text { on abundance; used unburned and burned clay, upland range } \\
\text { sites more than expected based on abundance }\end{array}$ \\
\hline
\end{tabular}




\begin{tabular}{|c|c|c|c|}
\hline $\begin{array}{l}\text { Buhnerkempe and } \\
\text { Westemeier } 1988\end{array}$ & Illinois & $\begin{array}{l}\text { Burned/hayed/seed- } \\
\text { harvested } \\
\text { tame/native } \\
\text { grassland; idle tame; } \\
\text { tame hayland; } \\
\text { pasture }\end{array}$ & $\begin{array}{l}\text { Preferred to nest in seeded grasses invaded by forbs, such as } \\
\text { young, rotary-mowed seedings and older, grass-seed } \\
\text { meadows, fields that were rotary mowed or burned the } \\
\text { previous season, and fields }>5 \text { yr after seeding, especially } \\
\text { those >8 yr old; nested in fields containing a mixture of } \\
\text { medium-height, narrow-leaved grasses, and forbs; nest cover } \\
\text { ranged from } 17 \text { to } 33 \mathrm{~cm} \text { high. Did not nest in brome } \\
\text { (Bromus) or wheat stubble/legume fields, fields that were } \\
\text { homogeneous in terms of vegetation, grass meadows } \\
\text { harvested for seed the previous year, vegetation }>60 \mathrm{~cm} \\
\text { high, and tall, rank prairie grasses. Broods used wheat } \\
\text { stubble, recently hayed legumes, redtop (Agrostis } \\
\text { stolonifera) fields intermixed with weeds, and moderately } \\
\text { grazed pastures }\end{array}$ \\
\hline $\begin{array}{l}\text { Buss and Hawkins } \\
1939\end{array}$ & Wisconsin & $\begin{array}{l}\text { Cropland, idle } \\
\text { tallgrass, tallgrass } \\
\text { pasture, } \\
\text { tallgrass/tame } \\
\text { hayland, tame } \\
\text { pasture, tame } \\
\text { hayland }\end{array}$ & $\begin{array}{l}\text { Nested in pastures planted to Junegrass (Koeleria sp.) and } \\
\text { canary grass (Phalaris sp.), in haylands planted to timothy } \\
\text { (Phleum pratense) or to a mixture of Junegrass, timothy, and } \\
\text { quackgrass (Agropyron repens), and in clumps of long, } \\
\text { dense grass arched over nests; two nests were placed in } \\
\text { alfalfa and sweet clover (Melilotus sp.) hayland; other nests } \\
\text { were placed at the base of forbs or shrubs in prairies; early } \\
\text { nests were in pasture and later nests in idle native grassland; } \\
\text { territories included loafing, nesting, and feeding sites; } \\
\text { suitable loafing areas were pastures with low-growing } \\
\text { clumps, sparsely vegetated grassland, and open hayland }\end{array}$ \\
\hline Cole and Sharpe 1976 & Nebraska & Idle, pasture & Preferred grazed over ungrazed areas \\
\hline $\begin{array}{l}\text { Colwell and Oring } \\
1990\end{array}$ & Saskatchewan & $\begin{array}{l}\text { Mixed-grass/tame } \\
\text { pasture, wet-meadow } \\
\text { pasture, wetland }\end{array}$ & $\begin{array}{l}\text { Nested in tall, dense, homogeneous upland vegetation }>15 \\
\text { cm in height }\end{array}$ \\
\hline
\end{tabular}




\begin{tabular}{|c|c|c|c|}
\hline Dale 1984 & Saskatchewan & $\begin{array}{l}\text { Idle mixed-grass, } \\
\text { mixed-grass pasture }\end{array}$ & Nested in grazed but not ungrazed plots \\
\hline $\begin{array}{l}\text { Dorio } 1977, \\
\text { Dorio and Grewe } \\
1979\end{array}$ & Minnesota & $\begin{array}{l}\text { Cropland, idle tame, } \\
\text { tame pasture, wet- } \\
\text { meadow hayland, } \\
\text { wetland, woodland }\end{array}$ & $\begin{array}{l}\text { Foraged in overgrazed pastures, sedge/grass meadows, and } \\
\text { plowed and seeded fields; during May and June, used } \\
\text { overgrazed pastures; in May, used sedge/grass meadow; } \\
\text { used mowed red clover (Trifolium pratense) fields for late } \\
\text { summer foraging (vegetation } 2.5-15.0 \mathrm{~cm} \text { tall). Nested in } \\
\text { oldfields, pastures of smooth brome, and wet meadow } \\
\text { (annually mowed sedge, timothy, and Canada bluegrass } \\
\text { [Poa compressa]); and in quackgrass, yarrow (Achillea } \\
\text { millefolium), and goldenrod (Solidago sp.); nests were found } \\
\text { in live vegetation ranging from } 22.5 \text { to } 35.0 \text { cm tall, and in } \\
\text { dead and matted vegetation; nests had a mean cover } \\
\text { frequency of } 25.2 \% \text { litter and } 12.0 \% \text { bare ground; Broods } \\
\text { used oldfields (Canada bluegrass, timothy, quackgrass, } \\
\text { western sagewort [Artemisia campestris], horse-weed } \\
\text { [Conyza canadensis], yarrow, and goldenrod), open areas } \\
\text { within oldfields, and overgrazed pastures; young and adults } \\
\text { foraged in vegetation < } 10 \text { cm tall; dry conditions allowed } \\
\text { marginal land, including open areas within oldfields, to be } \\
\text { plowed and planted to corn, reducing much of the brood- } \\
\text { rearing area and forcing broods to move to the edge }\end{array}$ \\
\hline $\begin{array}{l}\text { Ducey and Miller } \\
1980\end{array}$ & Nebraska & $\begin{array}{l}\text { Cropland, idle, } \\
\text { mixed-grass pasture, } \\
\text { tame hayland }\end{array}$ & $\begin{array}{l}\text { Preferred untilled areas such as alfalfa and pasture; foraged } \\
\text { in pasture and in corn fields before corn emerged or when } \\
\text { corn still was short }\end{array}$ \\
\hline Eddleman 1974 & Kansas & $\begin{array}{l}\text { Burned tallgrass, } \\
\text { burned tallgrass } \\
\text { pasture, idle tallgrass, } \\
\text { tallgrass pasture, wet }\end{array}$ & $\begin{array}{l}\text { Used heavily grazed/annually burned pasture, moderately } \\
\text { grazed/unburned pasture, and ungrazed/burned areas }\end{array}$ \\
\hline
\end{tabular}




\begin{tabular}{|c|c|c|c|}
\hline & & meadow & \\
\hline $\begin{array}{l}\text { Faanes and Lingle } \\
1995\end{array}$ & Nebraska & $\begin{array}{l}\text { Cropland, idle } \\
\text { mixed-grass, idle } \\
\text { shortgrass, idle } \\
\text { tallgrass, pasture, } \\
\text { sand-sage grassland, } \\
\text { tame hayland, wet } \\
\text { meadow, wetland, } \\
\text { woodland }\end{array}$ & $\begin{array}{l}\text { Nest density was highest in wet prairie, followed by } \\
\text { domestic hayland, upland prairie, wheat, alfalfa, and prairie } \\
\text { wetland; woody encroachment into wet prairie and } \\
\text { conversion of upland prairie to cropland negatively impacted } \\
\text { Upland Sandpipers }\end{array}$ \\
\hline Goering 1964 & Kansas & $\begin{array}{l}\text { Burned tallgrass } \\
\text { pasture, idle, idle } \\
\text { native/tame, idle } \\
\text { pasture, pasture } \\
\text { tallgrass pasture }\end{array}$ & $\begin{array}{l}\text { Foraged within burned pasture. Nested within dense stands } \\
\text { of ungrazed big and little bluestem (Andropogon gerardii, } \\
\text { Schizachyrium scoparium, respectively); in spring-burned } \\
\text { three-awn (Aristida sp.); in heavily grazed smooth brome; in } \\
\text { clumps of yellow sweet clover (Melilotus officinalis) within } \\
\text { weedy, ungrazed brome; in burned bluestem } \\
\text { (Schizachyrium) meadow; in clumps of dropseed } \\
\text { (Sporobolus sp.) within weedy, heavily grazed bluestem; and } \\
\text { in ungrazed but spring-burned bluestem }\end{array}$ \\
\hline $\begin{array}{l}\text { Graber and Graber } \\
1963\end{array}$ & Illinois & $\begin{array}{l}\text { Cropland, hayland, } \\
\text { idle, idle grassland, } \\
\text { tame pasture, } \\
\text { wetland, woodland }\end{array}$ & $\begin{array}{l}\text { Nested in pasture and hayland, and foraged in cropland and } \\
\text { idle fields }\end{array}$ \\
\hline Higgins 1975 & North Dakota & $\begin{array}{l}\text { Burned/hayed idle, } \\
\text { cropland, idle, idle } \\
\text { mixed-grass, mixed- } \\
\text { grass pasture, tame } \\
\text { pasture, tame } \\
\text { hayland }\end{array}$ & $\begin{array}{l}\text { Commonly nested on untilled habitats, but also in summer } \\
\text { fallow, mulched stubble, standing stubble, and growing } \\
\text { grain }\end{array}$ \\
\hline
\end{tabular}




\begin{tabular}{|c|c|c|c|}
\hline Higgins et al. 1969 & $\begin{array}{l}\text { North Dakota, } \\
\text { South Dakota }\end{array}$ & $\begin{array}{l}\text { Cropland, hayland, } \\
\text { idle tame, idle } \\
\text { mixed-grass, pasture }\end{array}$ & $\begin{array}{l}\text { Nested in idle or intermittently hayed grassland (pastures or } \\
\text { highway rights-of-way) characterized by grasses ranging } \\
\text { from } 15 \text { to } 61 \mathrm{~cm} \text { in height, with medium density, and } \\
\text { abundant ground litter; one nest was found in alfalfa and } \\
\text { smooth brome; grasses used as nesting cover were little } \\
\text { bluestem, needle-and-thread, porcupine-grass (Stipa } \\
\text { spartea), green needlegrass, Junegrass (Koeleria } \\
\text { pyramidata), blue grama (Bouteloua gracilis), smooth } \\
\text { brome, Kentucky bluegrass, quackgrass, and crested } \\
\text { wheatgrass (Agropyron cristatum) }\end{array}$ \\
\hline $\begin{array}{l}\text { Huber and Steuter } \\
1984\end{array}$ & South Dakota & $\begin{array}{l}\text { Burned mixed-grass } \\
\text { pasture, mixed-grass } \\
\text { pasture }\end{array}$ & Used burned areas more than unburned areas \\
\hline Hull et al. 1996 & Kansas & $\begin{array}{l}\text { CRP (burned seeded- } \\
\text { native, idle seeded- } \\
\text { native) }\end{array}$ & $\begin{array}{l}\text { Were present in fields with medium frequency of occurrence } \\
\text { (mean of } 50.1 \% \text { ) of forbs }\end{array}$ \\
\hline Johnsgard 1980 & Nebraska & $\begin{array}{l}\text { Cropland, hayland, } \\
\text { idle, idle mixed- } \\
\text { grass, idle shortgrass, } \\
\text { idle tallgrass, mixed- } \\
\text { grass pasture, } \\
\text { tallgrass pasture, } \\
\text { tame hayland, wet } \\
\text { meadow }\end{array}$ & $\begin{array}{l}\text { Used native mixed- and tallgrass prairie, wet meadows, } \\
\text { hayland, retired croplands, and small grain }\end{array}$ \\
\hline $\begin{array}{l}\text { Johnson and Igl 1995, } \\
\text { Johnson and Schwartz } \\
1993\end{array}$ & $\begin{array}{l}\text { Minnesota, } \\
\text { Montana, } \\
\text { North Dakota, } \\
\text { South Dakota }\end{array}$ & $\begin{array}{l}\text { Cropland, CRP (idle } \\
\text { seeded-native, idle } \\
\text { tame) }\end{array}$ & $\begin{array}{l}\text { Were fairly common in CRP throughout the northern Great } \\
\text { Plains study area, but more common in cropland than CRP } \\
\text { in North Dakota }\end{array}$ \\
\hline
\end{tabular}




\begin{tabular}{|c|c|c|c|}
\hline Kaiser 1979 & South Dakota & $\begin{array}{l}\text { Idle mixed-grass, idle } \\
\text { mixed- } \\
\text { grass/tallgrass, idle } \\
\text { tallgrass, idle tame, } \\
\text { mixed-grass pasture, } \\
\text { mixed-grass/tallgrass } \\
\text { pasture, tallgrass } \\
\text { pasture, tame } \\
\text { hayland }\end{array}$ & $\begin{array}{l}\text { Preferred to nest on climax mixed-grass and tallgrass prairie, } \\
\text { although nests were found in Kentucky bluegrass, native } \\
\text { forbs, western wheatgrass, and green needlegrass; nest } \\
\text { success did not differ between matted and upright residual } \\
\text { vegetation; nests occurred in vegetation between } 12.7 \text { and } \\
63.5 \mathrm{~cm} \text { tall with } \geq 50 \% \text { vertical concealment by residual and } \\
\text { living vegetation; } 33 \% \text { of nests were concealed on all sides, } \\
55 \% \text { were concealed on two sides, and } 12 \% \text { had no side } \\
\text { concealment; avoided nesting in areas where vegetation } \\
\text { height was > } 60 \mathrm{~cm} \text {; nest success did not differ between nests } \\
\text { in tallgrass, mixed-/tallgrass transition, or mixed-grass; nest } \\
\text { densities did not differ between idle sites and sites that were } \\
\text { grazed in May (20-80\% of the current year's growth } \\
\text { removed); nested in grazed areas with varying grazing } \\
\text { pressure, ranging from } 1.0 \text { to } 2.5 \text { AUM }\end{array}$ \\
\hline Kantrud 1981 & North Dakota & $\begin{array}{l}\text { Mixed-grass hayland, } \\
\text { mixed-grass pasture }\end{array}$ & Highest densities in heavily grazed areas \\
\hline $\begin{array}{l}\text { Kantrud and Higgins } \\
1992\end{array}$ & $\begin{array}{l}\text { Manitoba, } \\
\text { Montana, } \\
\text { North Dakota, } \\
\text { South Dakota }\end{array}$ & $\begin{array}{l}\text { Burned mixed-grass, } \\
\text { cropland, hayland, } \\
\text { idle mixed-grass, idle } \\
\text { tame, mixed-grass } \\
\text { pasture }\end{array}$ & $\begin{array}{l}\text { Commonly nested in native grasslands, but readily nested in } \\
\text { tame grasses; nested in idle and grazed native grasslands, in } \\
\text { hayland, cropland, and burned areas; nested in grass- } \\
\text { dominated sites with } 100 \% \text { visual obstruction at }<15 \mathrm{~cm} \text {, } \\
\text { vegetation height }<30 \mathrm{~cm} \text {, and litter cover } 30-99 \% \text {; avoided } \\
\text { nesting where visual obstruction was }>40 \mathrm{~cm} \text { or height was } \\
>85 \mathrm{~cm} \text {; dominant nest vegetation included Kentucky } \\
\text { bluegrass, smooth brome, needle-and-thread, and } \\
\text { quackgrass; forbs and shrubs were dominant at very few } \\
\text { nests; nest success was higher in idle than in grazed fields }\end{array}$ \\
\hline $\begin{array}{l}\text { Kantrud and } \\
\text { Kologiski } 1982\end{array}$ & $\begin{array}{l}\text { Colorado, } \\
\text { Montana, } \\
\text { North Dakota, }\end{array}$ & $\begin{array}{l}\text { Mixed-grass pasture, } \\
\text { shortgrass pasture, }\end{array}$ & $\begin{array}{l}\text { Occurred at highest densities on moderately grazed typic } \\
\text { ustoll soils; areas considered to be the best habitat for } \\
\text { Upland Sandpipers were dominated by wheatgrass }\end{array}$ \\
\hline
\end{tabular}




\begin{tabular}{|c|c|c|c|}
\hline & $\begin{array}{l}\text { Nebraska, } \\
\text { South Dakota, } \\
\text { Wyoming }\end{array}$ & shrubsteppe & $\begin{array}{l}\text { (Agropyron) and Kentucky bluegrass, followed by green } \\
\text { needlegrass, buffalo grass (Buchloe dactyloides), western } \\
\text { snowberry, and slimspike three-awn (Aristida longiseta) }\end{array}$ \\
\hline Kendeigh 1941 & Iowa & $\begin{array}{l}\text { Idle tallgrass } \\
\text { (restored) }\end{array}$ & $\begin{array}{l}\text { Occurred in annually mowed prairie dominated by } \\
\text { porcupine-grass }\end{array}$ \\
\hline $\begin{array}{l}\text { King and Savidge } \\
1995\end{array}$ & Nebraska & $\begin{array}{l}\text { Cropland, burned } \\
\text { tallgrass; CRP } \\
\text { (burned seeded- } \\
\text { native, idle seeded- } \\
\text { native, idle tame, } \\
\text { tame hayland), idle } \\
\text { tallgrass, tallgrass } \\
\text { hayland }\end{array}$ & $\begin{array}{l}\text { Were found in native prairie and in CRP planted to native } \\
\text { grasses }\end{array}$ \\
\hline $\begin{array}{l}\text { Kirsch and Higgins } \\
1976\end{array}$ & North Dakota & $\begin{array}{l}\text { Cropland, burned } \\
\text { mixed-grass, idle } \\
\text { mixed-grass, idle } \\
\text { tame, mixed-grass } \\
\text { pasture }\end{array}$ & $\begin{array}{l}\text { Concealed nests in grassy vegetation; preferred nesting in } \\
\text { vegetation } 15.4-30.8 \mathrm{~cm} \text { in height and avoided nesting in } \\
\text { vegetation }>61.5 \mathrm{~cm} \text { tall; production, or mean number of } \\
\text { nests hatched/40.5 ha, was highest on burned grassland, } \\
\text { followed by undisturbed and grazed grassland; there was no } \\
\text { production on annually tilled croplands; production was } \\
\text { comparatively low on former cropland fields seeded to } \\
\text { grass-legume mixtures }\end{array}$ \\
\hline $\begin{array}{l}\text { Klute 1994, } \\
\text { Klute et al. } 1997\end{array}$ & Kansas & $\begin{array}{l}\text { Burned tallgrass } \\
\text { pasture; CRP (burned } \\
\text { seeded-native) }\end{array}$ & $\begin{array}{l}\text { Preferred large, unfragmented grassland areas; nested in } \\
\text { grazed pastures but not in CRP; preferred burned pasture to } \\
\text { burned CRP }\end{array}$ \\
\hline Lindmeier 1960 & Minnesota & $\begin{array}{l}\text { Cropland, hayland, } \\
\text { idle tallgrass, } \\
\text { wetland }\end{array}$ & $\begin{array}{l}\text { Nested in grassy depressions, in short grasses (little } \\
\text { bluestem, Junegrass, and muhly [Muhlenbergia spp.]), in } \\
\text { completely undisturbed areas, and in alfalfa; vegetation } \\
\text { height within } 10 \mathrm{~d} \text { after the first egg was laid averaged } 25.4\end{array}$ \\
\hline
\end{tabular}




\begin{tabular}{|c|c|c|c|}
\hline & & & $\begin{array}{l}\mathrm{cm} \text {, and consisted largely of residual vegetation; standing } \\
\text { vegetation over Upland Sandpiper nests was fairly thin, with } \\
\text { a light intensity average of } 222 \text { candles } / \mathrm{m}^{2} \text {; fire reduced } \\
\text { Upland Sandpiper numbers from about } 35 \text { to about } 25 \text { birds, } \\
\text { perhaps due to about } 75 \% \text { reduction in nesting cover }\end{array}$ \\
\hline $\begin{array}{l}\text { Lokemoen and Beiser } \\
1997\end{array}$ & North Dakota & Cropland, idle & $\begin{array}{l}\text { Nested mainly in growing wheat when its form was similar } \\
\text { to open grassland; nested in minimum-tillage and organic } \\
\text { fields but not fields subjected to conventional tillage }\end{array}$ \\
\hline $\begin{array}{l}\text { Lokemoen and } \\
\text { Duebbert } 1974\end{array}$ & South Dakota & $\begin{array}{l}\text { Burned mixed-grass, } \\
\text { idle mixed-grass, } \\
\text { mixed-grass hayland, } \\
\text { mixed-grass pasture }\end{array}$ & Nested in high density on idle, mowed, and burned prairie \\
\hline $\begin{array}{l}\text { Luttschwager and } \\
\text { Higgins } 1992\end{array}$ & South Dakota & $\begin{array}{l}\text { CRP (idle seeded- } \\
\text { native, idle tame, } \\
\text { seeded-native } \\
\text { hayland, tame } \\
\text { hayland) }\end{array}$ & Nest in hayed strips and idle fields \\
\hline Messmer 1985 & North Dakota & $\begin{array}{l}\text { Idle mixed- } \\
\text { grass/tame, mixed- } \\
\text { grass/tame pasture }\end{array}$ & $\begin{array}{l}\text { Highest nesting densities and nesting success on twice-over } \\
\text { deferred (pastures grazed twice per season with 2-mo rest } \\
\text { between grazing) pastures and season-long (leaving cattle on } \\
\text { the same pasture all season) pastures (with some undisturbed } \\
\text { nesting cover during the nesting season) than idle pastures }\end{array}$ \\
\hline Messmer 1990 & North Dakota & $\begin{array}{l}\text { Idle mixed- } \\
\text { grass/tame, mixed- } \\
\text { grass/tame hayland, } \\
\text { mixed-grass/tame } \\
\text { pasture, wet-meadow } \\
\text { pasture }\end{array}$ & $\begin{array}{l}\text { Highest densities found in short-duration grazed (system of } \\
\text { pastures rotated through a grazing schedule of about } 1 \mathrm{wk} \\
\text { grazed and } 1 \text { mo ungrazed, repeated throughout the season) } \\
\text { pastures, followed by twice-over deferred and season-long; } \\
\text { as range conditions on the short-duration pasture improved } \\
\text { and cover increased, density decreased; used previously }\end{array}$ \\
\hline
\end{tabular}




\begin{tabular}{|c|c|c|c|}
\hline & & & idled areas only after mowing \\
\hline Musselman 1935 & $\begin{array}{l}\text { Illinois, } \\
\text { Missouri }\end{array}$ & Idle tame & $\begin{array}{l}\text { Nested in abandoned clover (no scientific name provided) } \\
\text { fields and grass }\end{array}$ \\
\hline $\begin{array}{l}\text { Niemi and Hanowski } \\
1983\end{array}$ & Minnesota & $\begin{array}{l}\text { Idle tallgrass, } \\
\text { peatland, shrub carr, } \\
\text { wetland }\end{array}$ & $\begin{array}{l}\text { Predominant forbs within territories were bedstraw (Galium } \\
\text { spp.), goldenrod, and clover (Trifolium spp.); mean habitat } \\
\text { measurements from } 40 \text { sampling points within four } \\
\text { territories were } 79 \mathrm{~cm} \text { vegetation height, } 35 \% \text { ground cover, } \\
\text { (coverage of live vegetation with a total height of } \leq 10 \mathrm{~cm} \text { ), } \\
\text { and } 24 \mathrm{~cm} \text { phanerophyte (shrubs, forbs, or graminoids }>40 \\
\mathrm{~cm} \text { high and present each year) height }\end{array}$ \\
\hline $\begin{array}{l}\text { Oetting and Cassel } \\
1971\end{array}$ & North Dakota & Idle tame & Nested in road rights-of-way \\
\hline $\begin{array}{l}\text { Patterson 1994, } \\
\text { Patterson and Best } \\
1996\end{array}$ & Iowa & $\begin{array}{l}\text { Cropland, CRP (idle } \\
\text { tame, tame hayland) }\end{array}$ & Nested in CRP fields but not in cropland \\
\hline $\begin{array}{l}\text { Prescott and Wagner } \\
1996\end{array}$ & Alberta & $\begin{array}{l}\text { Mixed-grass pasture, } \\
\text { tame pasture }\end{array}$ & $\begin{array}{l}\text { Occurred only in deferred-grazed (grazed after } 15 \text { July) } \\
\text { native pastures, but not in continuously grazed native } \\
\text { pastures, native grassland grazed in early summer, or in tame } \\
\text { pastures of crested wheatgrass grazed in spring from late } \\
\text { April to mid-June }\end{array}$ \\
\hline Pylypec 1991 & Saskatchewan & $\begin{array}{l}\text { Burned mixed-grass, } \\
\text { idle mixed-grass }\end{array}$ & Occurred in recently burned areas 2-3 yr postburn \\
\hline $\begin{array}{l}\text { Renken 1983, } \\
\text { Renken and Dinsmore } \\
1987\end{array}$ & North Dakota & $\begin{array}{l}\text { Dense nesting cover } \\
\text { (DNC ; idle tame), } \\
\text { idle mixed-grass, } \\
\text { mixed-grass pasture }\end{array}$ & $\begin{array}{l}\text { Used idle and grazed native grassland, and alfalfa- } \\
\text { wheatgrass dense nesting cover, and areas } 1 \text { yr postgrazing; } \\
\text { used plots with less grass, less forb cover, less tall and dense } \\
\text { vegetation, and with a thinner litter layer than unused plots; } \\
\text { used areas characterized by } 57.4 \% \text { grass cover, } 23.5 \% \text { forb }\end{array}$ \\
\hline
\end{tabular}




\begin{tabular}{|c|c|c|c|}
\hline & & & $\begin{array}{l}\text { cover, } 98.8 \% \text { litter cover, } 5.7 \% \text { shrub cover, } 0.5 \% \text { bare } \\
\text { ground, } 11 \mathrm{~cm} \text { effective vegetation height, and } 2.3 \mathrm{~cm} \text { litter } \\
\text { depth }\end{array}$ \\
\hline Robel et al. 1998 & Kansas & $\begin{array}{l}\text { CRP (burned seeded- } \\
\text { native, idle seeded- } \\
\text { native) }\end{array}$ & $\begin{array}{l}\text { Were present only on spring-burned CRP fields but not on } \\
\text { unburned CRP fields }\end{array}$ \\
\hline $\begin{array}{l}\text { Rotenberry and Wiens } \\
1980\end{array}$ & $\begin{array}{l}\text { Colorado, } \\
\text { Kansas, } \\
\text { Montana, } \\
\text { Nebraska, } \\
\text { Oklahoma, } \\
\text { Oregon, } \\
\text { South Dakota, } \\
\text { Texas, } \\
\text { Washington, } \\
\text { Wisconsin, } \\
\text { Wyoming }\end{array}$ & $\begin{array}{l}\text { Idle mixed-grass, idle } \\
\text { shortgrass, idle } \\
\text { shrubsteppe, idle } \\
\text { tallgrass, montane } \\
\text { meadow }\end{array}$ & $\begin{array}{l}\text { Abundance was positively correlated with total number of } \\
\text { vertical vegetation hits, and negatively correlated with } \\
\text { percent bare ground }\end{array}$ \\
\hline Sample 1989 & Wisconsin & $\begin{array}{l}\text { Burned tallgrass, } \\
\text { cropland, DNC (idle } \\
\text { seeded-native, idle } \\
\text { tame), idle, idle } \\
\text { seeded-native, idle } \\
\text { tallgrass, idle } \\
\text { tallgrass/tame, idle } \\
\text { tame, tame hayland, } \\
\text { tame pasture, tame } \\
\text { savanna pasture, wet } \\
\text { meadow, wet- } \\
\text { meadow pasture }\end{array}$ & $\begin{array}{l}\text { Preferred hayland and managed or disturbed grasslands; } \\
\text { avoided sites with woody vegetation; used areas with an } \\
\text { average of } 0.5 \% \text { woody cover, } 81 \% \text { herbaceous cover, } 15 \% \\
\text { litter cover, } 8 \% \text { bare ground, maximum vegetation height of } \\
45 \mathrm{~cm} \text {, and vegetation height/density of } 14 \mathrm{~cm} \text {; sandpiper } \\
\text { density was highest with a medium density (medium density } \\
\text { defined as }<3 \mathrm{~cm} \text { deep with }>50 \% \text { coverage) of prostrate } \\
\text { residual vegetation; density was negatively correlated to } \\
\text { total percent woody cover, total number of dead stems, } \\
\text { maximum vegetation height, and height/density values }\end{array}$ \\
\hline
\end{tabular}




\begin{tabular}{|c|c|c|c|}
\hline Sedivec 1994 & North Dakota & $\begin{array}{l}\text { Idle mixed-grass, } \\
\text { mixed-grass pasture }\end{array}$ & $\begin{array}{l}\text { Used grazed areas for nesting more often than ungrazed } \\
\text { areas; nested in vegetation with average height/density of } \\
11.8 \mathrm{~cm}\end{array}$ \\
\hline Skinner 1974, 1975 & Missouri & $\begin{array}{l}\text { Idle tallgrass, idle } \\
\text { tame, tallgrass } \\
\text { hayland, tallgrass } \\
\text { pasture, tame } \\
\text { hayland, tame } \\
\text { pasture }\end{array}$ & $\begin{array}{l}\text { Nest density was highest under moderate grazing (vegetation } \\
10.2-30.4 \mathrm{~cm} \text { tall) and heavy grazing }(0-10.2 \mathrm{~cm} \text { tall); also } \\
\text { present in hayland, combined fields, and lightly grazed } \\
\text { pasture ( }>30.4 \mathrm{~cm} \text { tall); not present in idle fields }\end{array}$ \\
\hline $\begin{array}{l}\text { Skinner 1982, } \\
\text { Skinner et al. } 1984\end{array}$ & Missouri & $\begin{array}{l}\text { Burned tallgrass, idle } \\
\text { tallgrass, tallgrass } \\
\text { hayland, tallgrass } \\
\text { pasture, tame pasture }\end{array}$ & $\begin{array}{l}\text { Were found in short cover typical of heavily grazed areas } \\
\text { (low grass and forb cover); nested in pasture among small } \\
\text { clumps of grass and forbs (grasslands with this vegetation } \\
\text { structure occurred on moderately to heavily grazed prairie } \\
\text { and on April-burned prairie) }\end{array}$ \\
\hline Snyder et al. 1987 & Indiana & $\begin{array}{l}\text { Cropland, idle } \\
\text { tallgrass, idle tame }\end{array}$ & $\begin{array}{l}\text { Used oat fields in spring until fields were harvested; foraged } \\
\text { in mowed areas and idle tallgrass areas; bred in idle } \\
\text { tallgrass; perched on utility and light poles }\end{array}$ \\
\hline $\begin{array}{l}\text { Speirs and Orenstein } \\
1967\end{array}$ & Ontario & $\begin{array}{l}\text { Cropland, idle, } \\
\text { pasture, tame } \\
\text { hayland }\end{array}$ & Used lightly grazed pasture \\
\hline $\begin{array}{l}\text { Sutter and Brigham } \\
1998\end{array}$ & Saskatchewan & $\begin{array}{l}\text { Mixed-grass pasture, } \\
\text { tame pasture }\end{array}$ & $\begin{array}{l}\text { Were present in low abundances in both mixed-grass pasture } \\
\text { and pastures of crested wheatgrass }\end{array}$ \\
\hline White 1980, 1983 & Wisconsin & $\begin{array}{l}\text { Cropland, hayland, } \\
\text { idle tallgrass, burned } \\
\text { pasture, pasture, } \\
\text { woodland }\end{array}$ & $\begin{array}{l}\text { Preferred non-forested areas, smooth terrain, presence of } \\
\text { fence posts (or other areas for display, such as tree stumps } \\
\text { and rock piles), unfragmented agricultural fields, and fields } \\
\text { of hay, oats, or pasture rather than corn; nested in pastures, } \\
\text { both burned and unburned, in prairie, and in hayfields }\end{array}$ \\
\hline
\end{tabular}




\begin{tabular}{|l|l|l|l|}
\hline $\begin{array}{l}\text { Wilson and Belcher } \\
1989\end{array}$ & Manitoba & $\begin{array}{l}\text { Idle mixed-grass, idle } \\
\text { tame }\end{array}$ & $\begin{array}{l}\text { Abundance was positively correlated with presence of native } \\
\text { vegetation and negatively correlated with presence of tame } \\
\text { vegetation }\end{array}$ \\
\hline Zimmerman 1993 & Kansas & $\begin{array}{l}\text { Burned tallgrass, } \\
\text { idle, idle tallgrass, } \\
\text { woodland }\end{array}$ & $\begin{array}{l}\text { Nested in watersheds that were not burned in spring; greatest } \\
\text { frequency of relative abundance and mean relative } \\
\text { abundance were in annually burned grassland, probably due } \\
\text { to foraging use; was common on unburned grassland }\end{array}$ \\
\hline
\end{tabular}

*In an effort to standardize terminology among studies, various descriptors were used to denote the management or type of habitat. "Idle" used as a modifier (e.g., idle tallgrass) denotes undisturbed or unmanaged (e.g., not burned, mowed, or grazed) areas. "Idle" by itself denotes unmanaged areas in which the plant species were not mentioned. Examples of "idle" habitats include weedy or fallow areas (e.g., oldfields), fencerows, grassed waterways, terraces, ditches, and road rights-of-way. "Tame" denotes introduced plant species (e.g., smooth brome [Bromus inermis]) that are not native to North American prairies. "Hayland" refers to any habitat that was mowed, regardless of whether the resulting cut vegetation was removed. "Burned" includes habitats that were burned intentionally or accidentally or those burned by natural forces (e.g., lightning). In situations where there are two or more descriptors (e.g., idle tame hayland), the first descriptor modifies the following descriptors. For example, idle tame hayland is habitat that is usually mowed annually but happened to be undisturbed during the year of the study. 


\section{LITERATURE CITED}

Ailes, I. W. 1976. Ecology of the Upland Sandpiper in central Wisconsin. M.S. thesis. University of Wisconsin, Stevens Point, Wisconsin. 63 pages.

Ailes, I. W. 1980. Breeding biology and habitat use of the Upland Sandpiper in central Wisconsin. Passenger Pigeon 42:53-63.

Ailes, I. W., and J. E. Toepfer. 1977. Home range and daily movement of radio-tagged Upland Sandpipers in central Wisconsin. Inland Bird Banding News 49:203-212.

Bates, J. M. 1907. The Bartramian Sandpiper. Bird-Lore 9:84.

Bent, A. C. 1962. Upland Plover. Pages 57-69 in Life histories of North American shorebirds. Part 2. Dover Publications, Inc., New York, New York.

Best, L. B., H. Campa, III, K. E. Kemp, R. J. Robel, M. R. Ryan, J. A. Savidge, H. P. Weeks, Jr., and S. R. Winterstein. 1997. Bird abundance and nesting in CRP fields and cropland in the Midwest: a regional approach. Wildlife Society Bulletin 25:864-877.

Birkenholz, D. E. 1973. Habitat relationships of grassland birds at Goose Lake Prairie Nature Preserve. Pages 63-66 in L. C. Hulbert, editor. Third Midwest Prairie Conference Proceedings. Kansas State University, Manhattan, Kansas.

Bollinger, E. K. 1995. Successional changes and habitat selection in hayfield bird communities. Auk 112:720-730.

Bolster, D. C. 1990. Habitat use by the Upland Sandpiper in northeastern Colorado. M.S. thesis. University of Colorado, Boulder, Colorado. 104 pages.

Bowen, B. S., and A. D. Kruse. 1993. Effects of grazing on nesting by Upland Sandpipers in southcentral North Dakota. Journal of Wildlife Management 57:291-301.

Bowen, D. E., Jr. 1976. Coloniality, reproductive success, and habitat interactions in Upland Sandpiper (Bartramia longicauda). Ph.D. thesis. Kansas State University, Manhattan, Kansas. 127 pages.

Bryan, G. G., and L. B. Best. 1991. Bird abundance and species richness in grassed waterways in Iowa rowcrop fields. American Midland Naturalist 126:90-102.

Buhnerkempe, J. E., and R. L. Westemeier. 1988. Breeding biology and habitat of Upland Sandpipers on prairie chicken sanctuaries in Illinois. Transactions of the Illinois State Academy of Science 81:153-162.

Buss, I. O., and A. S. Hawkins. 1939. The Upland Plover at Faville Grove, Wisconsin. Wilson Bulletin 51:202-220. 
Cole, T., and R. S. Sharpe. 1976. The effects of grazing management on a sandhills prairie community. III. Breeding bird density and diversity. Proceedings of the Nebraska Academy of Science Affiliated Society 86:12.

Colwell, M. A., and L. W. Oring. 1990. Nest site characteristics of prairie shorebirds. Canadian Journal of Zoology 68:297-302.

Dale, B. C. 1984. Birds of grazed and ungrazed grasslands in Saskatchewan. Blue Jay 42:102105.

Dorio, J. C. 1977. Nesting and brood rearing habitat of the Upland Sandpiper in central Minnesota. M.A. thesis. St. Cloud State University, St. Cloud, Minnesota. 43 pages.

Dorio, J. C., and A. H. Grewe. 1979. Nesting and brood rearing habitat of the Upland Sandpiper. Journal of the Minnesota Academy of Science 45:8-11.

Ducey, J., and L. Miller. 1980. Birds of an agricultural community. Nebraska Bird Review 48:58-68.

Eddleman, W. R. 1974. The effects of burning and grazing on bird populations in native prairie in the Kansas Flint Hills. Unpublished report, National Science FoundationUndergraduate Research Program. Kansas State University, Manhattan, Kansas. 33 pages.

Eldridge, J. 1992. Management of habitat for breeding and migrating shorebirds in the Midwest. U.S. Fish and Wildlife Service Leaflet 13.2.14. 6 pages.

Faanes, C. A., and G. R. Lingle. 1995. Breeding birds of the Platte River Valley of Nebraska. Jamestown, ND: Northern Prairie Wildlife Research Center home page. http://www.npwrc.usgs.gov/resource/distr/birds/platte/platte.htm (Version 16JUL97).

Friedmann, H. 1963. Host relations of the parasitic cowbirds. U.S. National Museum Bulletin 233:1-276.

Friedmann, H., and L. F. Kiff. 1985. The parasitic cowbirds and their hosts. Proceedings of the Western Foundation of Vertebrate Zoology 2:226-304.

Goering, D. K. 1964. The Upland Plover in the Flint Hills of Kansas. M.S. thesis. Kansas State Teachers College of Emporia, Emporia, Kansas. 28 pages.

Graber, R. R., and J. W. Graber. 1963. A comparative study of bird populations in Illinois, 1906-1909 and 1956-1958. Illinois Natural History Survey Bulletin 28:383-528.

Griebel, R. L., S. L. Winter, and A. A. Steuter. 1998. Grassland birds and habitat structure in sandhills prairie management using cattle or bison plus fire. Great Plains Research 8:255-268. 
Helzer, C. J. 1996. The effects of wet meadow fragmentation on grassland birds. M.S. thesis. University of Nebraska, Lincoln, Nebraska. 65 pages.

Helzer, C. J., and D. E. Jelinski. 1999. The relative importance of patch area and perimeter-area ratio to grassland breeding birds. Ecological Applications 9:1448-1458.

Herkert, J. R. 1991a. An ecological study of the breeding birds of grassland habitats within Illinois. Ph.D. dissertation. University of Illinois, Urbana, Illinois. 112 pages.

Herkert, J. R. 1991b. Prairie birds of Illinois: population response to two centuries of habitat change. Illinois Natural History Survey Bulletin 34:393-399.

Herkert, J. R. 1991c. Study suggests increases in restored prairie fragments to conserve breeding bird communities. Restoration and Management Notes 9:107.

Herkert, J. R. 1994. Breeding bird communities of midwestern prairie fragments: the effects of prescribed burning and habitat-area. Natural Areas Journal 14:128-135.

Herkert, J. R., R. E. Szafoni, V. M. Kleen, and J. E. Schwegman. 1993. Habitat establishment, enhancement and management for forest and grassland birds in Illinois. Illinois Department of Conservation, Division of Natural Heritage, Natural Heritage Technical Publication 1, Springfield, Illinois. 20 pages.

Higgins, K. F. 1975. Shorebird and game bird nests in North Dakota croplands. Wildlife Society Bulletin 3:176-179.

Higgins, K. F., H. F. Duebbert, and R. B. Oetting. 1969. Nesting of the Upland Plover on the Missouri Coteau. Prairie Naturalist 1:45-48.

Higgins, K. F., and L. M. Kirsch. 1975. Some aspects of the breeding biology of the Upland Sandpiper in North Dakota. Wilson Bulletin 87:96-102.

Huber, G. E., and A. A. Steuter. 1984. Vegetation profile and grassland bird response to spring burning. Prairie Naturalist 16:55-61.

Hull, S. D., R. J. Robel, and K. E. Kemp. 1996. Summer avian abundance, invertebrate biomass, and forbs in Kansas CRP. Prairie Naturalist 28:1-12.

Johnsgard, P. A. 1980. A preliminary list of the birds of Nebraska and adjacent Plains states. University of Nebraska, Lincoln, Nebraska. 156 pages.

Johnson, D. H. 1997. Effects of fire on bird populations in mixed-grass prairie. Pages 181-206 in F. L. Knopf and F. B. Samson, editors. Ecology and conservation of Great Plains vertebrates. Springer-Verlag, New York, New York.

Johnson, D. H., and L. D. Igl. 1995. Contributions of the Conservation Reserve Program to populations of breeding birds in North Dakota. Wilson Bulletin 107:709-718. 
Johnson, D. H., and M. D. Schwartz. 1993. The Conservation Reserve Program: habitat for grassland birds. Great Plains Research 3:273-295.

Kaiser, P. H. 1979. Upland Sandpiper (Bartramia longicauda) nesting in southeastern South Dakota, USA. Proceedings of the South Dakota Academy of Science 58:59-68.

Kantrud, H. A. 1981. Grazing intensity effects on the breeding avifauna of North Dakota native grasslands. Canadian Field-Naturalist 95:404-417.

Kantrud, H. A., and K. F. Higgins. 1992. Nest and nest site characteristics of some groundnesting, non-passerine birds of northern grasslands. Prairie Naturalist 24:67-84.

Kantrud, H. A., and R. L. Kologiski. 1982. Effects of soils and grazing on breeding birds of uncultivated upland grasslands of the northern Great Plains. U.S. Fish and Wildlife Service, Wildlife Research Report 15. 33 pages.

Kendeigh, S. C. 1941. Birds of a prairie community. Condor 43:165-174.

King, J. W., and J. A. Savidge. 1995. Effects of the Conservation Reserve Program on wildlife in southeast Nebraska. Wildlife Society Bulletin 23:377-385.

Kirsch, L. M., and K. F. Higgins. 1976. Upland Sandpiper nesting and management in North Dakota. Wildlife Society Bulletin 4:16-20.

Klute, D. S. 1994. Avian community structure, reproductive success, vegetative structure, and food availability in burned Conservation Reserve Program fields and grazed pastures in northeastern Kansas. M.S. thesis. Kansas State University, Manhattan, Kansas. 168 pages.

Klute, D. S., R. J. Robel, and K. E. Kemp. 1997. Will conversion of Conservation Reserve Program (CRP) lands to pasture be detrimental for grassland birds in Kansas? American Midland Naturalist 137:206-212.

Lindmeier, J. P. 1960. Plover, rail, and godwit nesting on a study area in Mahnomen County, Minnesota. Flicker 32:5-9.

Lokemoen, J. T., and J. A. Beiser. 1997. Bird use and nesting in conventional, minimumtillage, and organic cropland. Journal of Wildlife Management 61:644-655.

Lokemoen, J. T., and H. F. Duebbert. 1974. Summer birds for a South Dakota prairie. South Dakota Conservation Digest 41:18-21.

Luttschwager, K. A., and K. F. Higgins. 1992. Nongame bird, game bird, and deer use of Conservation Reserve Program fields in eastern South Dakota. Proceedings of the South Dakota Academy of Science 71:31-36. 
Maher, W. J. 1973. Matador Project: Birds I. Population dynamics. Canadian Committee for the International Biological Programme, Matador Project, Technical Report 34. University of Saskatchewan, Saskatoon, Saskatchewan. 56 pages.

Messmer, T. A. 1985. Effects of specialized grazing systems on upland nesting birds in southcentral North Dakota. M.S. thesis. North Dakota State University, Fargo, North Dakota. 112 pages.

Messmer, T. A. 1990. Influence of grazing treatments on nongame birds and vegetation structure in south central North Dakota. Ph.D. dissertation. North Dakota State University, Fargo, North Dakota. 164 pages.

Musselman, T. E. 1935. Upland Plover (Bartramia longicauda) increasing in Adams County, Illinois. Auk 52:447.

National Geographic Society. 1987. Field guide to the birds of North America, second edition. National Geographic Society, Washington, D.C. 464 pages.

Niemi, G. J., and J. M. Hanowski. 1983. Habitat characteristics of Yellow Rail, Upland Sandpiper, and Sharp-tailed Sparrow territories. Lake Superior Basin Studies Center, University of Minnesota, Duluth, Minnesota. 15 pages.

Oetting, R. B., and J. F. Cassel. 1971. Waterfowl nesting on interstate highway right-of-way in North Dakota. Journal of Wildlife Management 35:774-781.

Patterson, M. P. 1994. Bird species abundance, composition, and vegetation characteristics, and bird productivity in Conservation Reserve Program land in central Iowa. M.S. thesis. Iowa State University, Ames, Iowa. 54 pages.

Patterson, M. P., and L. B. Best. 1996. Bird abundance and nesting success in Iowa CRP fields: the importance of vegetation structure and composition. American Midland Naturalist 135:153-167.

Prescott, D. R. C., and G. M. Wagner. 1996. Avian responses to implementation of a complementary/ rotational grazing system by the North American Waterfowl Management Plan in southern Alberta: the Medicine Wheel Project. NAWMP-018. Alberta NAWMP Centre, Edmonton, Alberta. 24 pages.

Pylypec, B. 1991. Impacts of fire on bird populations in a fescue prairie. Canadian FieldNaturalist 105:346-349.

Renken, R. B. 1983. Breeding bird communities and bird-habitat associations on North Dakota waterfowl production areas of three habitat types. M.S. thesis. Iowa State University, Ames, Iowa. 90 pages.

Renken, R. B., and J. J. Dinsmore. 1987. Nongame bird communities on managed grasslands in North Dakota. Canadian Field-Naturalist 101:551-557. 
Robel, R. J., J. P. Hughes, S. D. Hull, K. E. Kemp, and D. S. Klute. 1998. Spring burning: resulting avian abundance and nesting in Kansas CRP. Journal of Range Management 51:132-138.

Rotenberry, J. T., and J. A. Wiens. 1980. Habitat structure, patchiness, and avian communities in North American steppe vegetation: a multivariate analysis. Ecology 61:1228-1250.

Salt, W. R., and J. R. Salt. 1976. The birds of Alberta. Hurtig Publishers, Edmonton, Alberta. 498 pages.

Sample, D. W. 1989. Grassland birds in southern Wisconsin: habitat preference, population trends, and response to land use changes. M.S. thesis. University of Wisconsin, Madison, Wisconsin. 588 pages.

Sedivec, K. K. 1994. Grazing treatment effects on and habitat use of upland nesting birds on native rangeland. Ph.D. dissertation. North Dakota State University, Fargo, North Dakota. 124 pages.

Skinner, R. M. 1974. Grassland use patterns and prairie bird populations in Missouri. M.A. thesis. University of Missouri, Columbia, Missouri. 53 pages.

Skinner, R. M. 1975. Grassland use patterns and prairie bird populations in Missouri. Pages 171-180 in M. K. Wali, editor. Prairie: a multiple view. University of North Dakota Press, Grand Forks, North Dakota.

Skinner, R. M. 1982. Vegetation structure and bird habitat selection on Missouri prairies. Ph.D. dissertation. University of Missouri, Columbia, Missouri. 108 pages.

Skinner, R. M., T. S. Baskett, and M. D. Blendon. 1984. Bird habitat on Missouri prairies. Terrestrial Series 14. Missouri Department of Conservation, Jefferson City, Missouri. 37 pages.

Snyder, D. L., V. Riemenschneider, and V. W. Inman. 1987. The Upland Sandpiper, Bartramia longicauda, breeding area in South Bend, Indiana. Proceedings of the Indiana Academy of Science 96:537-542.

Speirs, J. M., and R. Orenstein. 1967. Bird populations in fields of Ontario County, 1965. Canadian Field-Naturalist 81:175-183.

Stewart, R. E. 1975. Breeding birds of North Dakota. Tri-College Center for Environmental Studies, Fargo, North Dakota. 295 pages.

Sutter, G. C., and R. M. Brigham. 1998. Avifaunal and habitat changes resulting from conversion of native prairie to crested wheat grass: patterns at songbird community and species levels. Canadian Journal of Zoology 76:869-875.

U.S. Soil Conservation Service. 1984. Technician's guide to range sites and condition classes in North Dakota.. U.S.D.A. Soil Conservation Service, Bismarck, North Dakota. 
Vickery, P. D. 1993. Habitat selection of grassland birds in Maine. Ph.D. dissertation. University of Maine, Orono, Maine. 124 pages.

Vickery, P. D., M. L. Hunter, and S. M. Melvin. 1994. Effects of habitat area on the distribution of grassland birds in Maine. Conservation Biology 8:1087-1097.

White, R. P. 1980. Distribution and habitat preference of the Upland Sandpiper (Bartramia longicauda) in Wisconsin. M.S. thesis. University of Wisconsin, Madison, Wisconsin. 145 pages.

White, R. P. 1983. Distribution and habitat preference of the Upland Sandpiper (Bartramia longicauda) in Wisconsin. American Birds 37:16-22.

Wiens, J. A. 1969. An approach to the study of ecological relationships among grassland birds. Ornithological Monographs 8:1-93.

Wilson, S. D., and J. W. Belcher. 1989. Plant and bird communities of native prairie and introduced Eurasian vegetation in Manitoba, Canada. Conservation Biology 3:39-44.

Winter, M. 1998. Effect of habitat fragmentation on grassland-nesting birds in southwestern Missouri. Ph.D. dissertation. University of Missouri, Columbia, Missouri. 215 pages.

Zimmerman, J. L. 1993. Birds of Konza: the avian ecology of the tallgrass prairie. University of Kansas Press, Lawrence, Kansas. 186 pages. 